\title{
The genus Aspidimerus Mulsant, I 850 (Coleoptera, Coccinellidae) from China, with descriptions of two new species
}

\author{
Lizhi Huo ${ }^{1, \dagger}$, Xingmin Wang ${ }^{1, \neq}$, Xiaosheng Chen ${ }^{1, \S}$, Shunxiang Ren ${ }^{1,1}$ \\ I Engineering Research Center of Biological Control, Ministry of Education; College of Natural Resources and \\ Environment, South China Agricultural University, Guangzhou 510642, China \\ † http://zoobank.org/FA135086-13FD-4DF0-B5F9-8E3EE2111EF7 \\ $\ddagger$ http://zoobank.org/9A316497-BA7A-4FEC-B9F7-8E806E495D1E \\ § http://zoobank.org/BC0ABF82-220E-49B8-B849-E8CDED5C56D1 \\ | http://zoobank.org/3D26C274-7182-413F-8352-453BFB99437B \\ Corresponding author: Shunxiang Ren (shxren@scau.edu.cn)
}

Academic editor: N. Vandenberg | Received 6 June 2013 | Accepted 24 October 2013 | Published 8 November 2013

http://zoobank.org/329D52AA-93BF-4554-9D44-AAOAA2DOCF62

Citation: Huo L, Wang X, Chen X, Ren S (2013) The genus Aspidimerus Mulsant, 1850 (Coleoptera, Coccinellidae) from China, with descriptions of two new species. ZooKeys 348: 47-75. doi: 10.3897/zookeys.348.5746

\begin{abstract}
Chinese members of the genus Aspidimerus Mulsant, 1850 are reviewed. Ten species are recognized, including two new species: A. zhenkangicus Huo \& Ren, sp. n. and A. menglensis Huo \& Ren, sp. n. $A$. kabakovi Hoàng is recorded from China for the first time. A. blandus (Mader, 1954) is recognized as synonymous with A. ruficrus Gorham, 1895 (syn. n.). Aspidimerus rectangulatus Kuznetsov \& Pang, 1991 and $A$. serratus Kuznetsov \& Pang, 1991 are transferred to the genus Pseudaspidimerus Kapur, 1948 (comb. n.). All species from China are described and illustrated. Distribution maps of the Chinese species, a key and a catalogue of all known Aspidimerus are provided.
\end{abstract}

\section{Keywords}

Coleoptera, Coccinellidae, Aspidimerini, Aspidimerus, Pseudaspidimerus, new species, China

Copyright Lizhi Huo et al. This is an open access article distributed under the terms of the Creative Commons Attribution License 3.0 (CC-BY), which permits unrestricted use, distribution, and reproduction in any medium, provided the original author and source are credited. 


\section{Introduction}

The genus Aspidimerus Mulsant, 1850 was erected with Aspidimerus spencii from India as the type species by monotypy. Concurrently, another genus Cryptogonus Mulsant was erected with Cryptogonus orbiculus (Gyllenhal, 1808) as the type species, also by monotypy. At the time of erecting these two genera, Mulsant had only one species for each genus, and separated them by the structure of the prosternum and the labrum which was covered or not by the clypeus. Chapuis (1876) and Weise (1885) considered these characters unreliable and the separation unwarranted as more species became known, and synonymised these two genera: Chapuis kept the name Cryptogonus whilst Weise preferred to retain Aspidimerus. After examining a large number of specimens, Weise (1900) considered that Aspidimerus and Cryptogonus were evidently different, based on the structure of male genitalia and consequently revived Cryptogonus, but separated them from the Scymnini, and assigned them to the present tribe Aspidimerini. Kapur (1948) revised the tribe Aspidimerini and erected two new genera: Acarinus and Pseudaspidimerus.

In the revision of the tribe Aspidimerini (Kapur, 1948), only three species of Aspidimerus were included: A. spencii Mulsant, 1850, A. ruficrus Gorham, 1895 and A. birmanicus (Gorham, 1895). But Kapur did not study A. nigrovittatus Motschulsky, 1866 nor $A$. mouhoti Crotch, 1874, which were listed by Korschefsky (1931) in the Coleopterorum Catalogus. Subsequently, Sasaji (1968) described two species $A$. esakii and A. matsumurai from Taiwan, China. Pang and Mao (1979) added another two species $A$. sexmaculatus and $A$. decemmaculatus from Yunnan, China. Hoàng (1982) described four species $A$. laokayensis, A. dongpaoensis, A. chapaensis and A. kabakovi from Vietnam. Yu and Li (2004) added A. guangxiensis to the Aspidimerus fauna from Guangxi, China.

Recently, Kovár (2007) transferred Cryptogonus nigritus Pang \& Mao, 1979 and Cryptogonus blandus Mader, 1954 to Aspidimerus: Aspidimerus nigritus (Pang \& Mao, 1979) and Aspidimerus blandus (Mader, 1954). Aspidimerus dongpaoensis Hoàng, 1982 was synonymized with $A$. nigritus (Pang \& Mao, 1979) and $A$. sexmaculatus Pang \& Mao, 1979 with $A$. mouhoti Crotch, 1874. After examination of the specimens of $A$. blandus (Mader, 1954) collected from the type locality, we found that the characters of the adult, including the male genitalia, perfectly agreed with the descriptions and illustrations of $A$. ruficrus Gorham, 1895 given by Kapur (1948). Therefore, we consider A. blandus (Mader, 1954) a junior synonym of $A$. ruficrus Gorham, 1895.

Additionally, Kuznetsov and Pang (1991) described two species A. rectangulatus and $A$. serratus from Vietnam. Examination of the type series showed that the characters of the adults, including the male genitalia, are in perfect agreement with the diagnosis of Pseudaspidimerus Kapur, 1948. Therefore, these two species are transferred to the genus Pseudaspidimerus: P. rectangulatus (Kuznetsov \& Pang, 1991) (comb. n.) and P. serratus (Kuznetsov \& Pang, 1991) (comb. n.).

Until now, thirteen species of Aspidimerus have been described, all occurring in the Oriental Region. In this paper, ten species of Aspidimerus from China are 
revised, including two new species: $A$. zhenkangicus Huo \& Ren, sp. n. and $A$. menglensis Huo \& Ren, sp. n. Aspidimerus kabakovi Hoàng is recorded from China for the first time. Diagnoses, detailed descriptions, colored illustrations and distribution maps are provided for each species. A key and catalogue of all known species are also provided.

\section{Materials and methods}

The specimens examined were collected and preserved in 90\% ethanol. External morphology was observed with a dissecting stereo microscope (SteREO Discovery V20, Zeiss). The measurements were made with an ocular micrometer: total length, from apical margin of clypeus to apex of elytra (TL); total width, across both elytra at widest part (TW=EW); height, through the highest point of elytra to metaventrite $(\mathrm{TH})$; head width, including eyes $(\mathrm{HW})$; pronotal length, from the middle of anterior margin to the base of pronotum (PL); pronotal width at widest part (PW); elytral length, along the suture, from the apex to the base including the scutellum (EL). Male and female genitalia were dissected, cleared in a $10 \%$ solution of $\mathrm{NaOH}$ by boiling for several minutes, and examined with an Olympus BX51 compound microscope.

Images were photographed with digital cameras (AxioCam HRc and CoolsnapProcf \& CRI Micro*Color), connected to the dissecting microscope. The software AxioVision Rel. 4.8 and Image-Pro Plus 5.1 were used to capture images from both cameras, and photos were cleaned up and laid out in plates with Adobe Photoshop CS5.

Terminology follows Ślipiński (2007) and Ślipiński and Tomaszewska (2010). Specimens used in this study are deposited in the Department of Entomology, South China Agriculture University, Guangzhou, China (SCAU) and Institute of Zoology, Chinese Academy of Sciences (IOZ).

\section{Taxonomy}

\section{Genus Aspidimerus Mulsant, 1850}

http://species-id.net/wiki/Aspidimerus

Figs $1-11$

Aspidimerus Mulsant, 1850: 944. Type species: Aspidimerus spencii Mulsant, 1850, by monotypy.

Diagnosis. Aspidimerus is closely related to Cryptogonus Mulsant. However, it can be easily distinguished from the latter as follows: prosternum T-shaped, evenly convex (Fig. 2), prosternal lines as wide apart as the base of prosternal process; the area between them extremely convex and widening anteriorly to form a chin-band, usually 


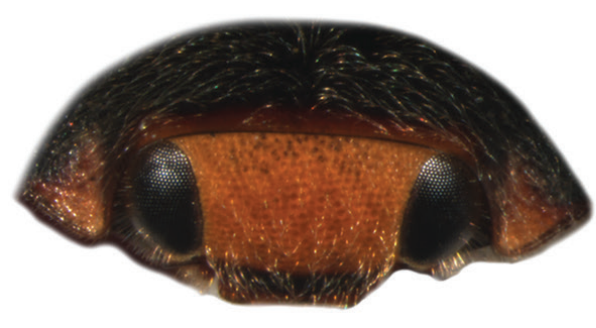

1

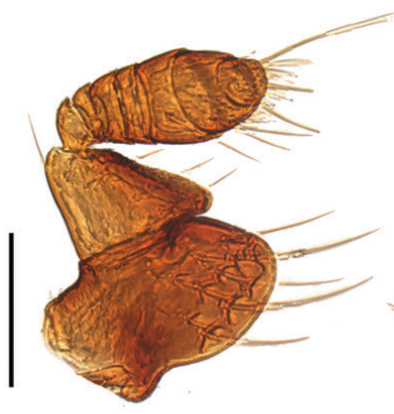

3

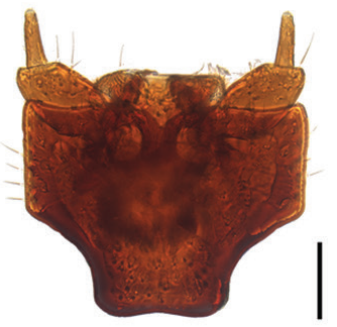

6

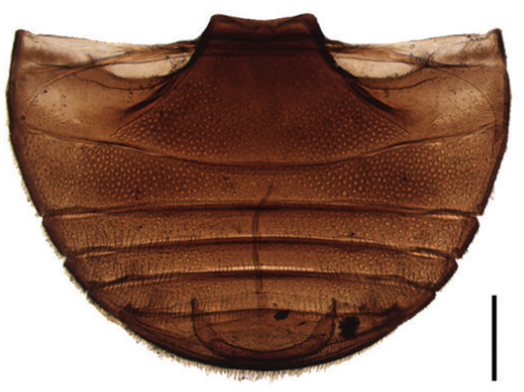

10

7

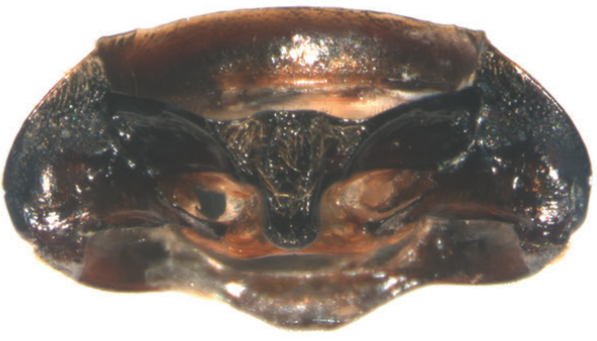

2
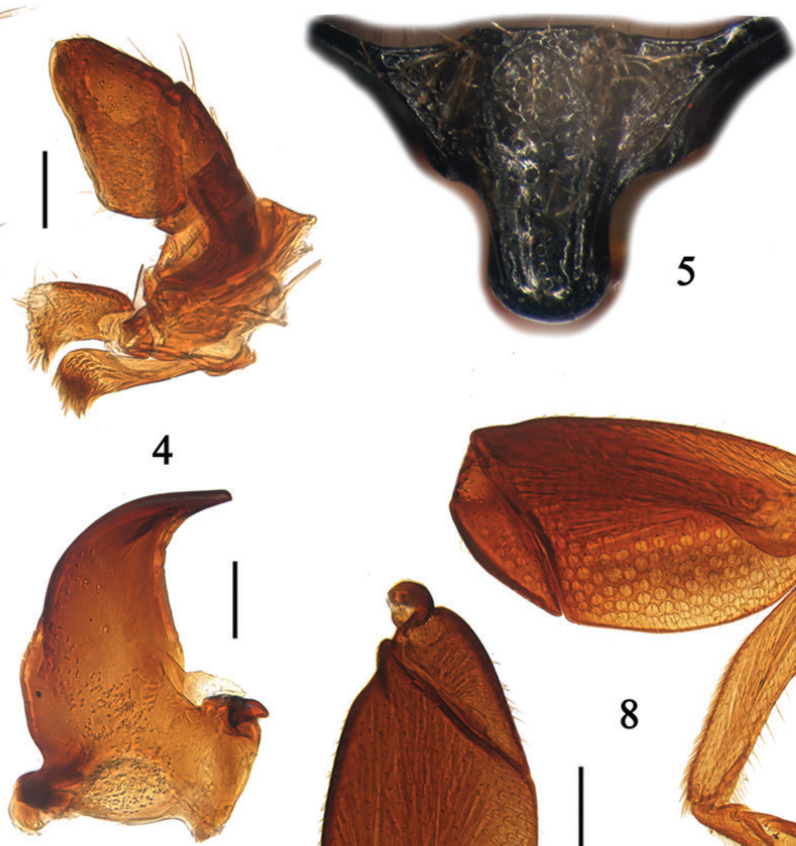

5

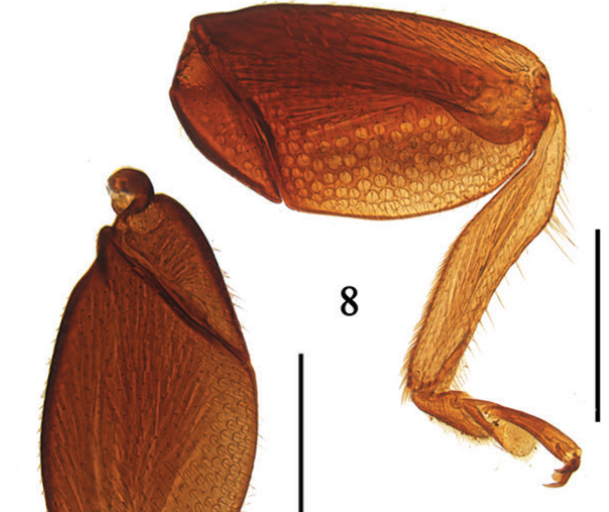

Figures I-II. A. matsumurai Sasaji, 1986. I head, frontal view $\mathbf{2}$ prothorax, ventral view $\mathbf{3}$ antenna $\mathbf{4}$ maxilla $\mathbf{5}$ prosternal process $\mathbf{6}$ labium $\mathbf{7}$ mandible $\mathbf{8}$ front leg $\mathbf{9}$ hind leg $\mathbf{1 0}$ abdomen $\mathbf{I} \mathbf{I}$ tarsi. Scale bars: Figures 1-7, 11: 0.1mm; Figures 8-10: $0.5 \mathrm{~mm}$. 
with coarse punctures and long pubescence (Fig. 5); body moderately large (length 2.8-5.0 $\mathrm{mm}$ ); oblong oval, moderately convex; pronotum with the posterior angles pointed and lateral margin straight (Fig. 1). The prosternal lines of Cryptogonus are not as in Aspidimerus, varying in outline, the area enclosed by them lying at the same level as the rest of prosternum; body small, rounded oval.

Description. Body moderately large, oblong oval, dorsum moderately convex, finely punctate and pubescent. Head transverse oval, eyes large, finely faceted, entire, narrowly margined and not extending to underside of head (Fig. 1). Antennae small, geniculate, composed of 8 or 9 antennomeres, antennomere 1 large, 2 slightly smaller and subtriangular, the rest together forming a spindle or an elongate oval club (Fig. 3). Terminal maxillary palpomere securiform (Fig. 4). Pronotum transverse, at middle of length twice as wide as long, strongly convex, anterior margin deeply emarginated. Scutellum subtriangular. Elytra oblong oval, moderately convex. Humeral callus rather prominent, obtusely.

Prosternum T-shaped, evenly convex (Fig. 2), prosternal lines as wide apart as the width of the base of the prosternal process, widely divergent; the area between them extremely convex and widening anteriorly to form a chin-band, usually with coarse punctures and long pubescence (Fig. 5). Both sides of prosternum deeply foveate to accommodate apices of front femora (Fig. 2). Mesoventrite transverse, widely emarginated anteriorly, indistinctly punctate and sparsely pubescent. Metaventrite usually finely punctate, with dense pubescence. Elytral epipleuron narrow, incomplete, with clearly delimited cavities to accommodate apices of mid and hind femora. Abdomen with 6 ventrites, the first being dilated posteriorly in an arc at middle, abdominal postcoxal lines incomplete (Fig. 10). Legs with femora broadly expanded, oval, and completely concealing the compressed tibiae (Figs 8-9), tarsi composed of three tarsomeres (Fig. 11).

Male genitalia: Penis curved, with a distinct penis capsule. Penis guide in ventral view flat and broad, apex pointed or truncate. Parameres slender, with sparsely distributed short setae at apex, nearly as long as penis guide. Female genitalia usually with tenth tergite broad, setose, coxites subtriangular or broad. Spermatheca vermiform, nodulus wide, ramus long.

Distribution. Burma, China, India, Laos, Sri Lanka, Thailand, Vietnam.

\section{Key to species of Aspidimerus Mulsant, 1850}

- Ground color of elytra yellowish brown or brown.

2 Elytra black without any spots, dorsum strongly convex and sparsely pubescent (Figs 12-14). Penis distinctly stout with pointed apex (Fig. 39), penis guide slender with hook-like apex in lateral view (Fig. 42). TL: $3.75 \mathrm{~mm}$, TW: $3.00 \mathrm{~mm}$, TH: $1.80 \mathrm{~mm}$. Distribution: China (Yunnan), Vietnam 
- $\quad$ Elytra black with spots, dorsum moderately convex and densely pubescent..... 3

$3 \quad$ Elytra black with 4 yellowish brown or red spots ..................................... 4

- Elytra black with 2 spots ........................................................................ 5

4 Elytra black with 4 yellowish brown spots (Fig. 15). Antennae with 8 antennomeres. Penis relatively long, slender and strongly curved, apex with membranous appendage (Fig. 43). Penis guide broad, widest at basal 1/3 with truncate apex in ventral view. TL: $3.60 \mathrm{~mm}$, TW: $2.90 \mathrm{~mm}$, TH: $1.75 \mathrm{~mm}$. Distribution: China (Hainan, Guangxi, Taiwan)

A. esakii Sasaji

- $\quad$ Elytra black with 4 red spots. Antennae with 9 antennomeres. TL: 3.60-3.90 mm, TW: 2.90-3.10mm. Distribution: Vietnam.............. A. chapaensis Hoàng

5 Penis relatively long, curved almost in a circle in whole length. Penis guide symmetrical with apex arcuate or truncate in ventral view............................6

- $\quad$ Penis short, curved at basal 1/3 length. Penis guide asymmetrical, with apex rounded or pointed in ventral view ........................................................... Elytra black with 2 yellow spots (Fig. 18). Penis guide moderately broad, symmetrical, almost parallel-sided with arcuate apex in ventral view, distinctly shorter than parameres (Fig. 50). TL: 3.50-3.90mm, TW: $2.65-3.15 \mathrm{~mm}$, TH: $1.50-1.75 \mathrm{~mm}$. Distribution: China (Yunnan)

A. menglensis Huo \& Ren, sp. n.

- $\quad$ Elytra black with 2 yellowish (in ${ }^{\top}$ ) or reddish brown spots (in 9 ). Penis guide narrow, symmetrical, slightly expanded in the middle and narrower towards the apex which is truncate. TL: $3.80-5.00 \mathrm{~mm}$, TW: $2.80-3.80 \mathrm{~mm}$. Distribution: Burma; Thailand A. birmanicus (Gorham) Elytra black with 2 yellowish brown spots (Fig. 21). Penis guide broad, widest at base, gradually narrowing to the apex, apex with a lateral hook-like process in ventral view (Fig. 54). Penis guide strongly curved, widest at base, strongly narrowing to apex in lateral view (Fig. 55). TL: $2.75-2.80 \mathrm{~mm}$, TW: 2.25-2.30mm, TH: 1.55-1.65mm. Distribution: China (Guangxi)...

A. guangxiensis Yu

Elytra black with 2 red (sometimes yellowish brown) spots (Fig. 24). Penis guide nearly parallel-sided at basal 6/7, then strongly and asymmetrically convergent to a pointed tip in ventral view (Fig. 58). Penis guide stout, spoon-shaped in lateral view (Fig. 59). TL: $3.75-4.60 \mathrm{~mm}$, TW: 3.00 $3.50 \mathrm{~mm}$, TH: $1.65-2.00 \mathrm{~mm}$. Distribution: China (Yunnan, Hainan, Taiwan), Vietnam A. matsumurai Sasaji

Ground color of elytra yellowish brown...............................................10

9 Body medium size, oblong oval. Upside clear brown with a large black marking in the middle of pronotum. TW: $4.60 \mathrm{~mm}$, TW: $3.40 \mathrm{~mm}$. Distribution: Vietnam 
- $\quad$ Body smaller, subrounded. Elytra brown with 4 black spots besides a black sutural spot (Fig. 27). TL: 2.85-3.50mm, TW: 2.40-2.85mm, TH: 1.25$1.75 \mathrm{~mm}$. Distribution: China (Guangdong, Guangxi, Yunnan), Vietnam....

A. kabakovi Hoàng

10 Elytra with 8 black spots and a black sutural stripe which expanded at near basal and apical part (Fig. 30). Penis short with penis capsule extremely expanded (Fig. 65). TL: 4.10mm, TW: 3.30mm, TH: 1.46mm. Distribution: China (Yunnan).

A. decemmaculatus Pang \& Mao

- $\quad$ Elytra with 6 black spots and a black sutural stripe which expanded near base (Figs 33, 36). Penis long with penis capsule slightly or moderately expanded

11 Pronotum brown; elytra without the black external border, suture with a narrow, black border between the scutellum and the middle; each elytron with 3 black spots. Distribution: India, Burma

A. spencii Mulsant

- $\quad$ Pronotum black; elytra with a narrow black external border all around the margins, that of the suture irregularly expanded in the basal half; each elytron with 3 spots

12 Penis guide stout, strongly curved in lateral view and with obtuse apex in ventral view (Figs 71-72). TL: 4.80mm, TW: 3.60mm, TH: 1.58mm. Distribution: China (Yunnan), Laos (Mouhot)

A. mouboti Crotch

- $\quad$ Penis guide slender, slightly curved in lateral view and with truncate apex in ventral view 13

13 Sutural stripe irregularly expanded as Fig. 33, the elytral spot nearer the suture as large as the one situated on humeral callus (Fig. 33). Penis capsule slightly expanded (Fig. 73). Penis guide widest at basal 2/5, gradually narrowing to apex, apex truncate in ventral view (Fig. 75). TL: 4.50-4.75mm, TW: 3.40-3.60mm, TH: 2.00-2.25mm. Distribution: China (Yunnan).

A. zhenkangicus Huo \& Ren, sp. n.

- $\quad$ Sutural stripe irregularly expanded as Fig. 36, the elytral spot nearer the suture distinctly larger than that situated on humeral callus (Fig. 36). Penis capsule moderately expanded (Fig. 79). Penis guide widest at middle, gradually narrowing to apex, margins of apical 1/6 almost parallel, apex truncate in ventral view (Fig. 81). TL: 3.75-4.00mm, TW: 3.00-3.25mm, TH: 1.55-1.65mm. Distribution: China (Sichuan, Yunnan), Vietnam, Burma A. ruficrus Gorham

Remarks. Aspidimerus nigrovittatus Motschulsky, 1866 is not keyed in the present paper, because the description given by Motschulsky (1866) is too simple to diagnose: "Subovatus, convexus, nitidus, sparsim puberulus, pallide flavus, elytris utrinque vitta lata nigra, apice non attinguenda”. Additionally, Kapur (1948) declared that its type was not available. 


\section{Aspidimerus nigritus (Pang \& Mao, 1979)}

http://species-id.net/wiki/Aspidimerus_nigritus

Figs 12-14, 39-42, 85

Cryptogonus nigritus Pang \& Mao, 1979: 61; Cao et al. 1992: 138.

Aspidimerus nigritus: Kovár 2007: 71, 73, 575; Ren et al. 2009: 108. Combined by Kovár 2007: 71.

Aspidimerus dongpaoensis Hoàng, 1982: 165. Synonymized by Kovár 2007: 73.

Diagnosis. This is a very distinctive species with body strongly convex and dorsal surface entirely black (Figs 12-14). Penis extremely short and stout (Fig. 39). Penis guide straight with hook-like apex in lateral view (Fig. 42). In ventral view, penis guide nearly parallel at basal half and then converging gradually to a blunted tip (Fig. 41).

Description. TL: $3.75 \mathrm{~mm}$, TW: $3.00 \mathrm{~mm}$, TH: $1.80 \mathrm{~mm}$, TL/TW: 1.25; PL/PW: 0.53; EL/EW: 0.88.

Body oblong oval, strongly convex and sparsely pubescent (Figs 12-14). Head reddish brown, eyes silver white (Fig. 14). Dorsal surface entirely black (Fig. 12). Underside reddish brown, except prosternum, mesoventrite and metaventrite dark brown.

Head small, 0.37 times elytral width $(\mathrm{HW} / \mathrm{EW}=1: 2.73)$. Punctures on frons sparsely distributed, separated by 1.0-3.0 times their diameter. Eyes large and almost oval, rather finely faceted, the widest interocular distance about 0.50 times head width. Punctures on dorsal surface fine, close, separated by $0.5-2.0$ times their diameter, with short, thin pubescence. Pronotum 0.67 times elytral width (PW/EW=1: 1.50). Surface of prosternum coarse, with sparse long pubescence. Mesoventrite with inconspicuous, rather sparse punctation. Punctures on metaventrite moderately large, separated by 0.3-1.0 times their diameter, with dense golden pubescence.

Male genitalia: Penis short, distinctly stout (Fig. 39). Penis capsule with a large outer process and an indistinct inner one (Fig. 39). Apex of penis pointed with membranous appendage (Fig. 40). Penis guide slender with hook-like apex in lateral view (Fig. 42). In ventral view, penis guide nearly parallel at basal half, and then converging gradually to a blunted tip (Fig. 41). Parameres stout, shorter than penis guide, with sparsely distributed long setae at its apex and inner side (Fig. 42).

Female genitalia: Unknown.

Specimens examined. China, Yunnan: $10^{\lambda}$, Menglun, Jinghong, $\left[21^{\circ} 55.51^{\prime} \mathrm{N}\right.$, $\left.101^{\circ} 15.45^{\prime} \mathrm{E}\right]$, ca 540m, 11.v.2009, Ren SX leg (SCAU).

Distribution. China (Yunnan); Vietnam.

\section{Aspidimerus esakii Sasaji, 1968}

http://species-id.net/wiki/Aspidimerus_esakii

Figs $15-17,43-47,85$

Aspidimerus esakii Sasaji, 1968: 16; 1986: 40; Pang and Mao 1979: 54; Pang 1998:

185; Yu 1995: 139; 2011: 166; Kovár 2007: 575; Ren et al. 2009: 106. 
Diagnosis. This species is close to $A$. chapaensis in general appearance, but can be separated from it by the black elytra with four yellow spots (Fig. 15), and the antennae with 8 antennomeres. In $A$. chapaensis, elytra black with four red spots and the antennae with 9 antennomeres. The spermatheca is also diagnostic according to the illustrations given by Sasaji (1968) and Hoàng (1982).

Description. TL: $3.70 \mathrm{~mm}$, TW: $2.90 \mathrm{~mm}$, TH: $1.75 \mathrm{~mm}$, TL/TW: 1.28; PL/PW: 0.53; EL/EW: 1.00 .

Body oblong oval, dorsum moderately convex and densely pubescent (Figs 15-17). Head yellowish brown, clypeus reddish brown, eyes black (Fig. 17). Pronotum black except anterior corners yellowish brown. Scutellum and elytra black. Each elytron with two yellowish brown spots (Figs 15-16). Underside black, except legs and abdomen reddish brown.

Head small, 0.45 times elytral width $(\mathrm{HW} / \mathrm{EW}=1: 2.23)$. Punctures on frons small, separated by $0.5-1.0$ times their diameter, with dense golden pubescence. Eyes large and oval, rather finely faceted, the widest interocular distance 0.50 times head width. Pronotum 0.69 times elytral width (PW/EW=1: 1.45), punctures on pronotum and scutellum fine, close, separated by 0.5-1.0 times their diameter, with thick, golden pubescence. Elytra finely punctate, with short yellow white pubescence. Surface of prosternum coarse, with sparse, long and yellowish pubescence. Punctures on metaventrite moderately large, separated by $0.5-1.0$ times their diameter, with dense yellowish pubescence.

Male genitalia: Penis relatively long, slender and strongly curved, apex of penis with membranous appendage, penis capsule with a short indistinct outer process and a long inner one (Figs 43-45). Penis guide slender, gradually tapering to apex forming a pointed tip in lateral view (Fig. 47). In ventral view, penis guide broad, widest at basal $1 / 3$ with truncate apex (Fig. 46). Parameres slender, sparsely setose at apex, equal in length to the penis guide (Fig. 47).

Specimens examined. China, Hainan: 1ð, Bawangling Natural Reserve, $\left[19^{\circ} 05.49^{\prime} \mathrm{N}, 109^{\circ} 06.38^{\prime} \mathrm{E}\right]$, ca 260m,5.v.2005, Wang XM leg (SCAU).

Distribution. China (Hainan, Guangxi, Taiwan).

\section{Aspidimerus menglensis Huo \& Ren, sp. n.}

http://zoobank.org/6F3968D5-DEE2-40C2-84FD-8D4A0D56D175

http://species-id.net/wiki/Aspidimerus_menglensis

Figs 18-20, 48-52, 85

Diagnosis. This species is similar to $A$. birmanicus (Gorham) in general appearance, but can be identified by the characters as follows: penis guide moderately broad, symmetrical, almost parallel-sided with arcuate apex in ventral view, distinctly shorter than parameres (Fig. 50), while in A. birmanicus (Gorham) penis guide narrow, slightly expanded in the middle and narrower towards the apex which is truncate.

It is also similar to A. guangxiensis in color pattern (Figs 18, 24), but can be distinguished from the latter by its larger size and male genitalia. 


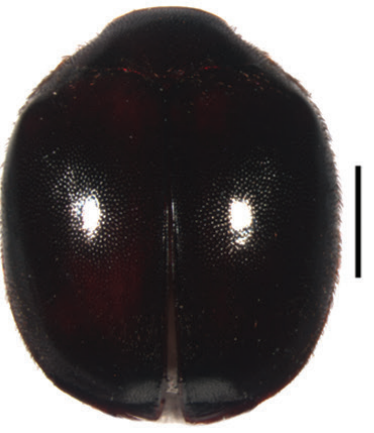

12

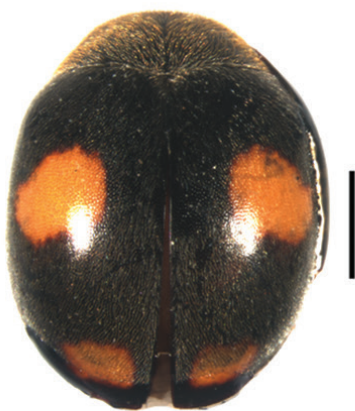

15

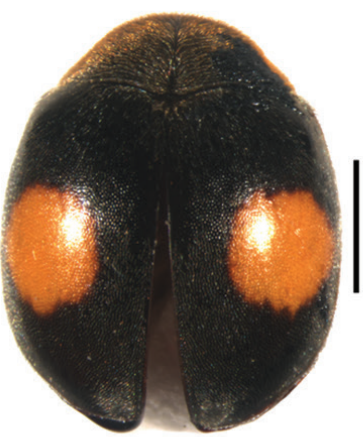

18

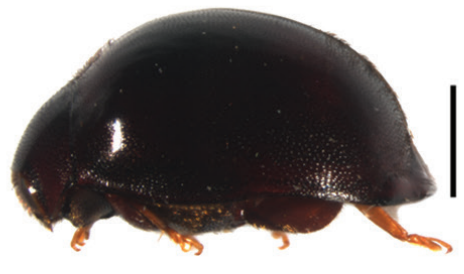

13

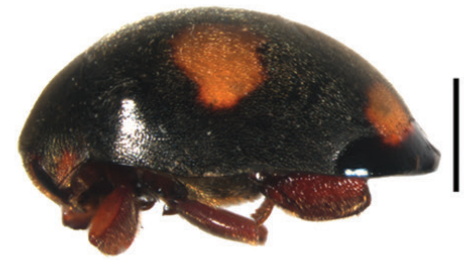

16

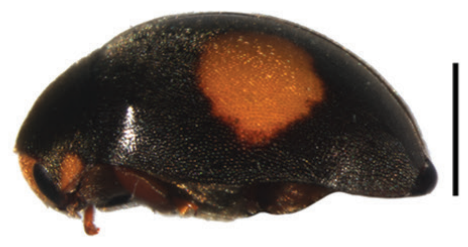

19
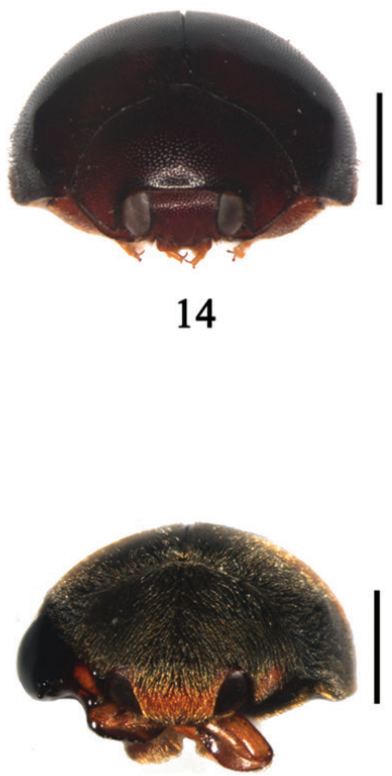

17

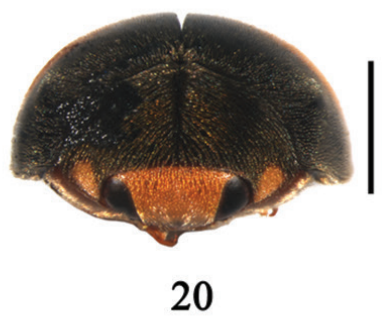

Figures | 2-20. I 2-I4 A. nigritus (Pang \& Mao), I $\mathbf{2}$ dorsal view 13 lateral view 14 frontal view 15-17 A. esakii Sasaji, 15 dorsal view 16 lateral view 17 frontal view 18-20 A. menglensis Huo \& Ren, sp. n. $\mathbf{1} 8$ dorsal view 19 lateral view 20 frontal view. Scale bars: $1.0 \mathrm{~mm}$.

Description. TL: $3.50-3.90 \mathrm{~mm}$, TW: $2.65-3.15 \mathrm{~mm}$, TH: $1.50-1.75 \mathrm{~mm}$, TL/ TW: 1.24-1.32; PL/PW: 0.51-0.55; EL/EW: 1.02-1.13.

Body oval, dorsum moderately convex and pubescent (Figs 18-20). Head yellow with the base brown in male and black in female. Clypeus reddish brown. Eyes black. Pronotum black except anterior corner yellow (Fig. 20). Scutellum black. Elytra black with two round yellow spots (Fig. 18). Underside black, except mesoventrite and legs brown. 


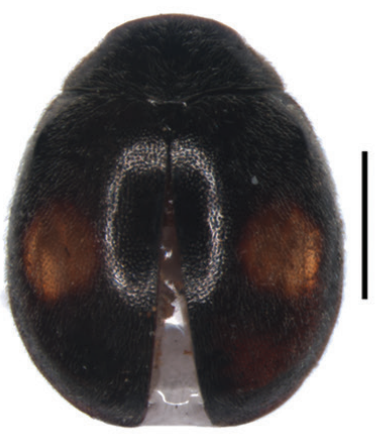

21

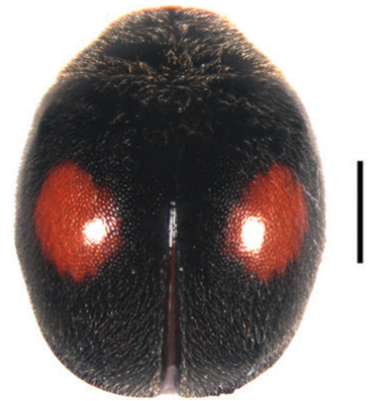

24

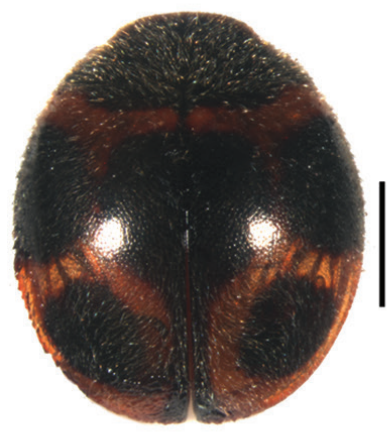

27

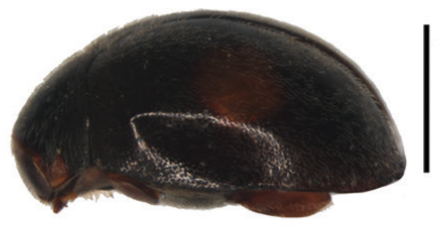

22
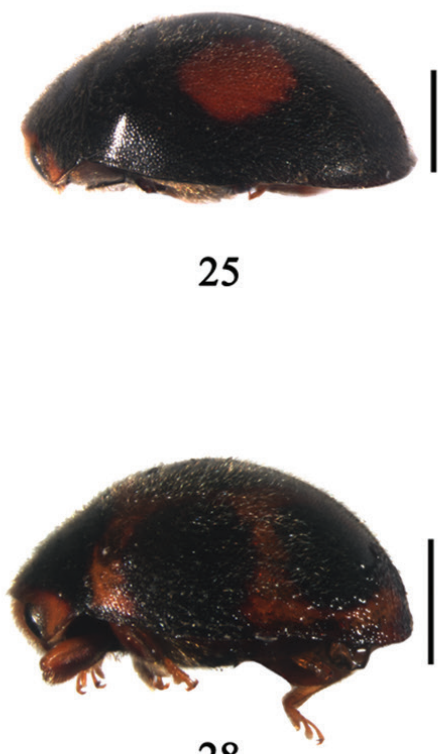

28

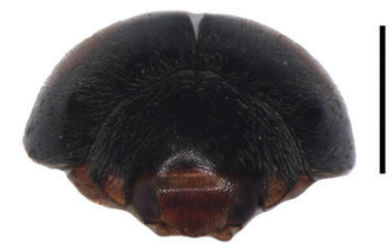

23

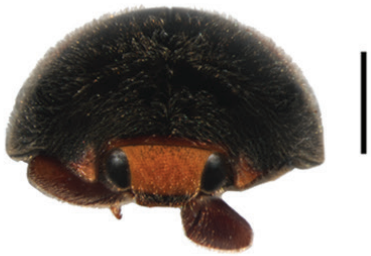

26

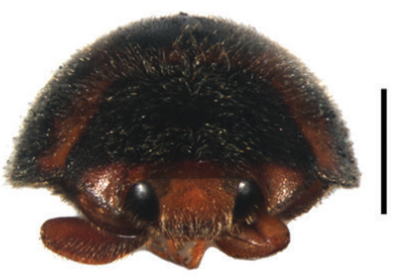

29

Figures 2I-29. 2I-23 A. guangxiensis Yu, 2 I dorsal view 22 lateral view 23 frontal view 24-26 . matsumurai Sasaji, 24 dorsal view 25 lateral view 26 frontal view 27-29 A. kabakovi Hoàng 27 dorsal view 28 lateral view 29 frontal view. Scale bars: $1.0 \mathrm{~mm}$.

Head small, 0.47 times elytral width $(\mathrm{HW} / \mathrm{EW}=1: 2.12)$. Punctures on frons fine, separated by $0.2-0.5$ times their diameter, with thick, golden pubescence. Eyes large and almost oval, rather finely faceted, the widest interocular distance 0.36 times head width. Pronotum 0.72 times elytral width $(\mathrm{PW} / \mathrm{EW}=1: 1.39)$, closely covered with small punctures and golden pubescence, denser than those on head, punctures separated by $0.5-1.0$ times their diameter. Punctures on elytra very fine and close, 
separated by $0.5-1.5$ times their diameter, with short silver white pubescence. Prosternum with sparse, coarse punctation and long pubescence. Mesoventrite small, with inconspicuous punctures and sparse pubescence. Metaventrite finely punctate, separated by $0.2-1.0$ times their diameter, with pubescence dense, short and silver white.

Male genitalia: Penis long, strongly curved. Penis capsule with a short outer process and a long inner one (Fig. 48). Apex of penis with membranous appendage (Fig. 49). Penis guide slender in lateral view (Fig. 51). In ventral view, penis guide symmetrical, almost parallel-sided with arcuate apex (Fig. 50); Parameres slender, longer than penis guide, with dense long setation at its apex and inner side (Fig. 50).

Female genitalia: Tenth tergite fairly broad, 0.25 times as long as wide, with moderately long setae. Coxites subtriangular, each with a few long terminal setae (Fig. 52).

Types. Holotype: $10^{\top}$, China, Yunnan: Mengla, Xishuangbanna, [21⒉ $26.59^{\prime} \mathrm{N}$, $101^{\circ} 38.01^{\prime} \mathrm{E}$ ], ca $1160 \mathrm{~m}$, 29.iv.2008, Wang XM leg. (SCAU). Paratypes (3): Yunnan: $1 \delta^{\top}$, Nanping, Mengla, $\left[21^{\circ} 39.55^{\prime} \mathrm{N}, 101^{\circ} 22.52^{\prime} \mathrm{E}\right]$, ca $750 \mathrm{~m}, 10 . v .2009$,

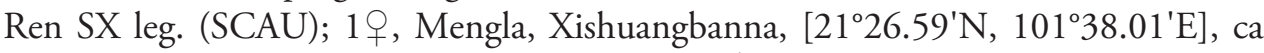
$1160 \mathrm{~m}, 29 . i v .2008$, Wang XM leg. (SCAU); $10^{\lambda}$, Longmen, Mengla, $\left[21^{\circ} 30.17^{\prime} \mathrm{N}\right.$, $\left.101^{\circ} 31.44^{\prime} \mathrm{E}\right]$, ca $760 \mathrm{~m}, 1 . v .2008$, Wang XM leg. (SCAU).

Distribution. China (Yunnan).

Etymology. The specific epithet refers to the type locality, Mengla, Yunnan.

\section{Aspidimerus guangxiensis Yu, 2004}

http://species-id.net/wiki/Aspidimerus_guangxiensis

Figs $21-23,53-55,85$

Aspidimerus guangxiensis Yu, 2004: 329; Ren et al. 2009: 106.

Diagnosis. This species is similar to $A$. matsumurai Sasaji in elytra with two spots (Figs $21,24)$, but can be distinguished from the latter by its smaller size and unique male genitalia: penis short, apical $1 / 2$ length with membranous appendage (Fig. 53), penis guide extremely broad, widest at base, gradually narrowing to the apex, apex with a lateral, hook-like process in ventral view (Fig. 54). In A. matsumurai, penis short, apical 2/5 length with less membranous appendage (Fig. 56), penis guide broad in ventral view, nearly parallel-sided at basal 6/7, then strongly and asymmetrically convergent to a pointed tip (Fig. 58).

Description. TL: $2.75-2.80 \mathrm{~mm}, \mathrm{TW}: 2.25-2.30 \mathrm{~mm}, \mathrm{TH}: 1.55-1.65 \mathrm{~mm}, \mathrm{TL} /$ TW: 1.25-1.30; PL/PW: 0.50-0.55; EL/EW: 0.91-1.11.

Body small, oval, moderately convex, dorsal surface pubescent (Figs 21-23). Head yellow or reddish brown with eyes black (Fig. 23). Pronotum black, with basal margin reddish brown and anterior corners yellowish brown. Scutellum and elytra black. Each elytron with one yellowish brown spot, rounded, situated at the middle of elytron (Fig. 21). Underside dark brown, except legs and abdomen reddish brown. 
Head small, 0.44 times elytral width $(\mathrm{HW} / \mathrm{EW}=1: 2.25)$. Punctures on frons fine, separated by 1.0-2.0 times their diameter, with short silver white setae. Eyes small, broadly oval, widest interocular distance 0.55 times head width (Fig. 20). Pronotum 0.67 times elytral width $(\mathrm{PW} / \mathrm{EW}=1: 1.50)$. Pronotal punctures fine, separated by 1.0-3.0 times their diameter. Scutellum triangular. Punctures on elytra slightly larger than those on pronotum, separated by 1.0-2.0 times their diameter. Prosternum coarse, with sparse punctation and long pubescence. Mesoventrite small, with a few setae. Metaventrite densely pubescent with punctures large and closely spaced, separated by $0.5-1.0$ times their diameter.

Male genitalia: Penis short and stout. Penis capsule with a distinctly outer process and a long inner one (Fig. 53). Penis guide widest at base and abruptly constricted forming a pointed apex in lateral view (Fig. 55). In ventral view, penis guide flat and asymmetrical, widest at base, gradually narrowing to the apex, apex with a lateral, hook-like process (Fig. 54). Parameres slender, sparsely setose at apex, shorter than penis guide (Fig. 55).

Female genitalia: Unknown.

Specimens examined. China, Guangxi: 1 $0^{\lambda}$, Shiwandashan Natural Reserve, Shangsi, [21 ${ }^{\circ} 54.36^{\prime} \mathrm{N}, 107^{\circ} 54.28^{\prime} \mathrm{E}$ ], ca 300m, 27.vii.2005, Zhang CW leg(SCAU);

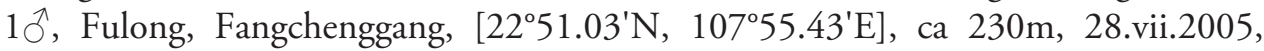
Wang XM leg (SCAU).

Distribution. China (Guangxi).

\section{Aspidimerus matsumurai Sasaji, 1968}

http://species-id.net/wiki/Aspidimerus_matsumurai

Figs 24-26, 56-60, 85

Aspidimerus matsumurai Sasaji, 1968: 17; Pang and Mao 1979: 53; Hoàng 1982: 162;

Cao and Xiao 1984: 98; Cao et al. 1992: 131; Pang 1998: 185; Kováŕ 2007: 575;

Ren et al. 2009: 108; Yu 2011: 167.

Diagnosis. This species is close to $A$. guangxiensis and A. birmanicus (Gorham) in dorsal coloration, but can be identified by the following characters: Penis stout and short. Penis capsule with a small inner process (Fig. 56). In ventral view, penis guide extremely broad, nearly parallel-sided at basal $6 / 7$, then strongly and asymmetrically convergent to a pointed tip (Fig. 58). In A. guangxiensis, penis guide widest at base, gradually narrowing to the apex, apex with a lateral hook-like process in ventral view (Fig. 54). In A. birmanicus, penis relatively long, penis capsule with a long inner process, penis guide distinctly narrower than that of $A$. matsumurai in ventral view.

A. matsumurai is also similar to $A$. laokayensis in male genitalia, but can be distinguished from the latter by its color pattern and detailed structure of genitalia.

Description. TL: $3.75-4.60 \mathrm{~mm}$, TW: $3.00-3.50 \mathrm{~mm}, \mathrm{TH}: 1.65-2.00 \mathrm{~mm}, \mathrm{TL} /$ TW: 1.25-1.31; PL/PW: 0.50-0.51; EL/EW: 0.97-1.03. 
Body oblong oval, moderately convex and pubescent (Figs 24-26). Head yellow with clypeus dark brown and eyes black (Fig. 26). Pronotum black except anterolateral corners and anterior margin yellowish brown (Fig. 26). Scutellum black. Elytra black with two round red (sometimes yellowish brown) spots (Fig. 24). Underside black, except legs and abdomen reddish brown.

Head small, 0.42 times elytral width $(\mathrm{HW} / \mathrm{EW}=1: 2.40)$. Punctures on frons close, separated by $0.3-0.5$ times their diameter, with thin, yellow white pubescence. Eyes large and broadly oval, rather finely faceted, widest interocular distance 0.60 times head width, posterior of the eye with silver setae. Pronotum 0.73 times elytral width $(\mathrm{PW} / \mathrm{EW}=1$ : 1.36). Pronotal punctures similar to those on head, separated by 0.5-1.5 times their diameter, with thick silver white pubescence. Punctures on elytra slightly larger than those on pronotum, separated by $0.5-1.0$ times their diameter. Prosternum coarsely punctate, with pubescence sparse, long and yellowish. Mesoventrite indistinctly punctate, with several hairs. Punctures on metaventrite fine, separated by $0.2-0.5$ times their diameter, with long setae.

Male genitalia: Penis stout and short, curved at basal $1 / 3$, gradually narrowing to the apex (Fig. 56). Apical 2/5 length of penis with membranous appendage. Penis capsule with a large outer process and a small inner one (Figs 56-57). Penis guide stout, spoon-shaped in lateral view (Fig. 59). In ventral view, penis guide very broad, nearly parallel-sided, slightly divergent apically, apical part asymmetrical, suddenly and strongly convergent to a blunted tip (Fig. 58). Parameres slender, sparsely setose at apex, slightly shorter than penis guide (Fig. 59).

Female genitalia: Tenth tergite broad, arc-shaped with terminal setae. Coxites broad, 0.4 times as long as wide, each with moderately long terminal setae (Fig. 60); spermatheca absent.

Specimens examined. China, Yunnan: 1 male, Nanping, Mengla, $\left[21^{\circ} 39.55^{\prime} \mathrm{N}\right.$, $\left.101^{\circ} 22.52^{\prime} \mathrm{E}\right]$, ca $740 \mathrm{~m}, 16 . v .2008$, Ren SX leg (SCAU); Hainan: $1{ }^{\top} 1$ 우, Diaoluoshan National Forest Park, [18 $\left.47.30^{\prime} \mathrm{N}, 109^{\circ} 52.58^{\prime} \mathrm{E}\right]$, ca $280 \mathrm{~m}$, 8.v.2005, Wang $\mathrm{XM}$ leg (SCAU).

Distribution. China (Yunnan, Hainan, Taiwan); Vietnam.

\section{Aspidimerus kabakovi Hoàng, 1982}

http://species-id.net/wiki/Aspidimerus_kabakovi

Figs 27-29, 61-64, 86

Aspidimerus kabakovi Hoàng, 1982: 167.

Diagnosis. This species can be easily distinguished by the following characters: elytra brown with 5 subrounded black spots disposed as Fig. 27. Apical 1/3 length of penis is very characteristic (Fig. 61). Penis guide broad, basal $2 / 3$ length nearly parallel-sided, apical 1/3 strongly convergent with rounded apex (Fig. 62). 
Description. TL: $2.85-3.50 \mathrm{~mm}$, TW: $2.40-2.85 \mathrm{~mm}$, TH: $1.25-1.75 \mathrm{~mm}$, TL/ TW: 1.19-1.23; PL/PW: 0.52; EL/EW: 0.94-0.96.

Body subrounded, dorsum moderately convex and pubescent (Figs 27-29). Head yellowish brown with clypeus reddish brown, eyes black or silver white. Pronotum black except anterior margin and anterior corners brown (Fig. 29). Scutellum black. Elytra brown with 5 subrounded black spots arranged as follows: 1 on the middle of suture and 2 on each elytron, the front larger, confluent with the border (Figs 27-28). Underside reddish brown, except prosternum, mesoventrite and metaventrite dark brown.

Head small, 0.42 times elytral width $(\mathrm{HW} / \mathrm{EW}=1: 2.40)$. Punctures on frons small, separated by $0.5-1.0$ times their diameter. Eyes large, widest interocular distance 0.60 times head width. Dorsal surface finely punctate, with dense, silver white pubescence. Pronotum 0.69 times elytral width $(\mathrm{PW} / \mathrm{EW}=1: 1.45)$. Underside finely punctate, with pubescence dense, short and silver white.

Male genitalia: Penis stout with apical $1 / 3$ length very characteristic as shown in Fig. 61. Penis capsule with distinct outer and inner processes (Fig. 61). Penis guide stout and slightly curved in lateral view (Fig. 63). In ventral view, penis guide broad, basal $2 / 3$ length nearly parallel-sided, apical $1 / 3$ strongly convergent with rounded apex (Fig. 62). Parameres slender, as long as the penis guide, sparsely setose at apex (Fig. 62).

Female genitalia: tenth tergite fairly broad, 0.15 times as long as wide, setaceous at apex, coxites subtriangular with a few long terminal setae (Fig. 64); spermatheca absent.

Specimens examined. China, Guangdong: $1 \hat{\partial}$, Nankunshan Natural Reserve, Huizhou, [2337.54'N, $113^{\circ} 52.56^{\prime} \mathrm{E}$ ], ca 490m, 5.viii.1986, Pang XF leg (SCAU); Guangxi: 1 , , Shiwandashan Natural Reserve, Shangsi, [21 ${ }^{\circ} 54.25^{\prime} \mathrm{N}, 107^{\circ} 54.33^{\prime} \mathrm{E}$ ], ca 380m, 9.ix.2004, Lv XB leg (SCAU); 10, Maoershan Natural Reserve, 18.x.2004, $\left[25^{\circ} 51.50^{\prime} \mathrm{N}, 110^{\circ} 25.10^{\prime} \mathrm{E}\right]$, ca $1350 \mathrm{~m}$, Wang XM leg (SCAU); $10^{\lambda}$, Fulong, Fangchenggang, [22 $05.19^{\prime} \mathrm{N}, 107^{\circ} 59.28^{\prime} \mathrm{E}$ ], ca $220 \mathrm{~m}$, 29.vii.2005, Qin ZQ leg

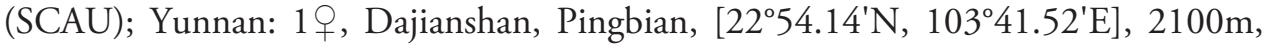
20.iv.2008, Wang XM leg (SCAU).

Distribution. China (Guangdong, Guangxi, Yunnan); Vietnam.

\section{Aspidimerus decemmaculatus Pang \& Mao, 1979}

http://species-id.net/wiki/Aspidimerus_decemmaculatus

Figs 30, 65-68, 86

Aspidimerus decemmaculatus Pang \& Mao, 1979: 56; Cao and Xiao 1984: 98; Cao et al. 1992: 134; Pang 1998: 186; Kovár 2007: 575; Ren et al. 2009: 106.

Diagnosis. This species can be easily distinguished from other Aspidimerus by the following characters: elytra with 8 black spots and a black sutural stripe which expanded at near basal and apical part (Fig. 30). Penis capsule extremely expanded (Fig. 65). Penis guide subtriangular, widest at base with rounded apex in ventral view (Fig. 67). 


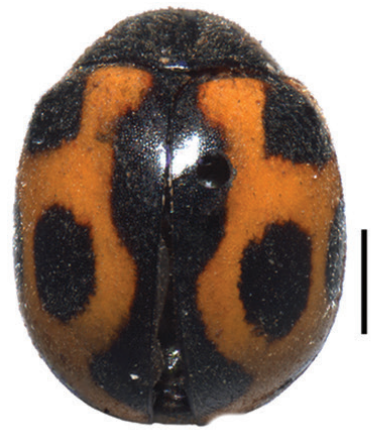

30

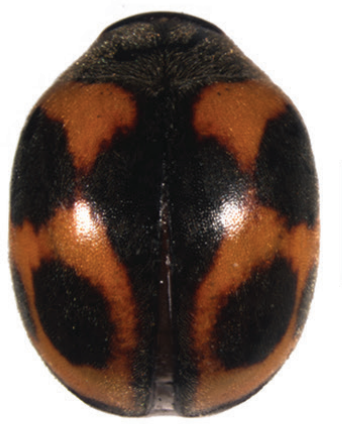

33

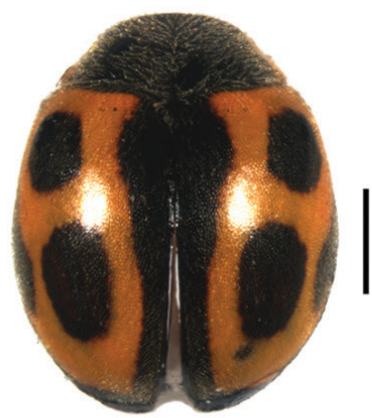

36
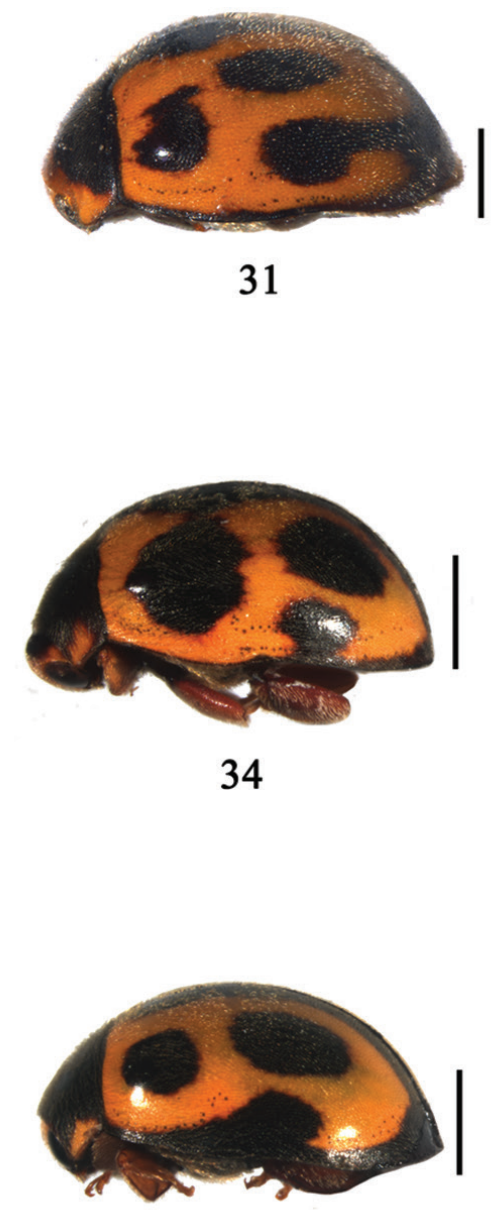

37

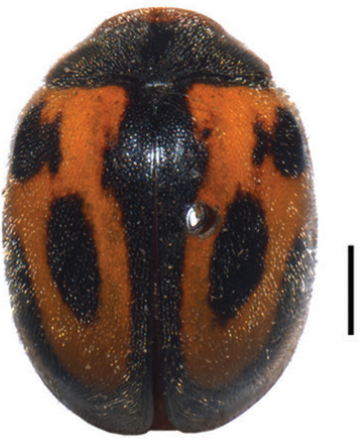

32

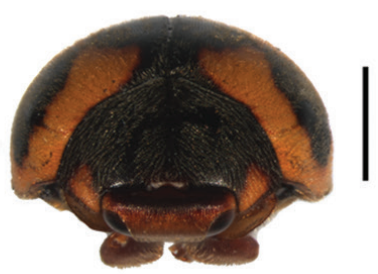

35

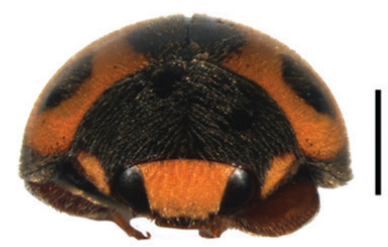

38

Figures 30-38. 30 A. decemmaculatus Pang \& Mao, dorsal view; 3I-32 A. mouhoti Crotch, 31 lateral view 32 dorsal view 33-35 A. zhenkangicus Huo \& Ren, sp. n. 33 dorsal view 34 lateral view 35 frontal view 36-38 A. ruficrus Gorham, $\mathbf{3 6}$ dorsal view $\mathbf{3 7}$ lateral view 38 frontal view. Scale bars: $1.0 \mathrm{~mm}$.

Description. TL: $4.10 \mathrm{~mm}$, TW: $3.30 \mathrm{~mm}$, TH: $1.46 \mathrm{~mm}$, TL/TW: 1.24; PL/PW: 0.39; EL/EW: 1.09 .

Body large, oblong oval, dorsum moderately convex and pubescent (Fig. 30). Head yellowish brown with eyes black. Pronotum black, with anterior corners yellowish brown. Scutellum black. Elytra yellowish brown. Elytral margins black. Each 


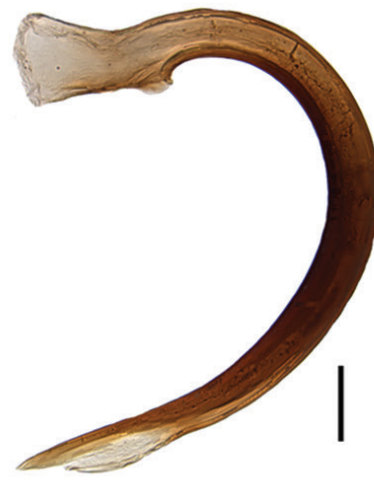

39

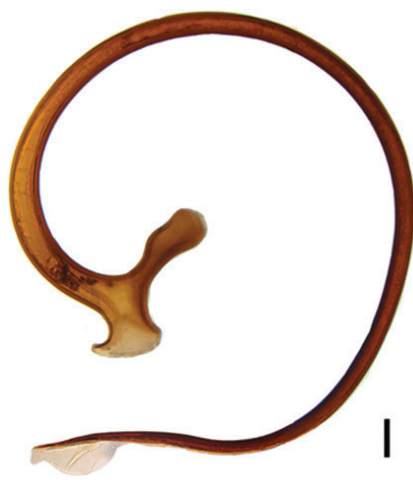

43

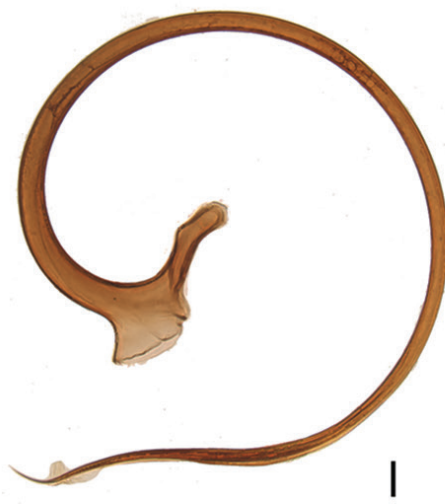

48

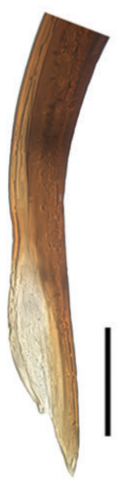

40

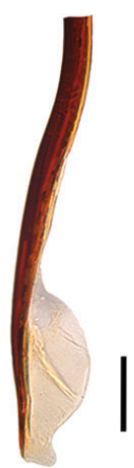

44

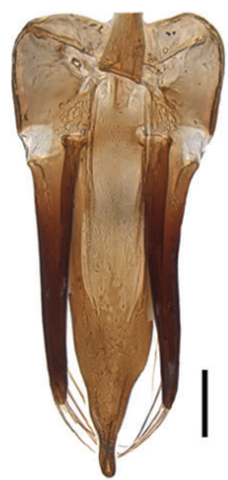

41

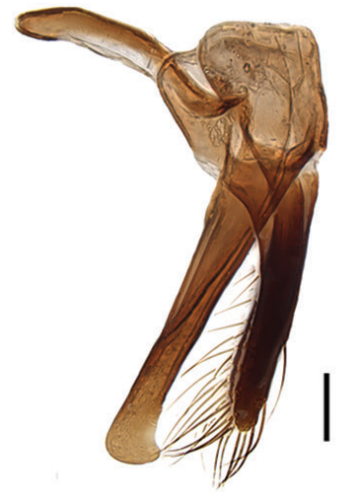

42

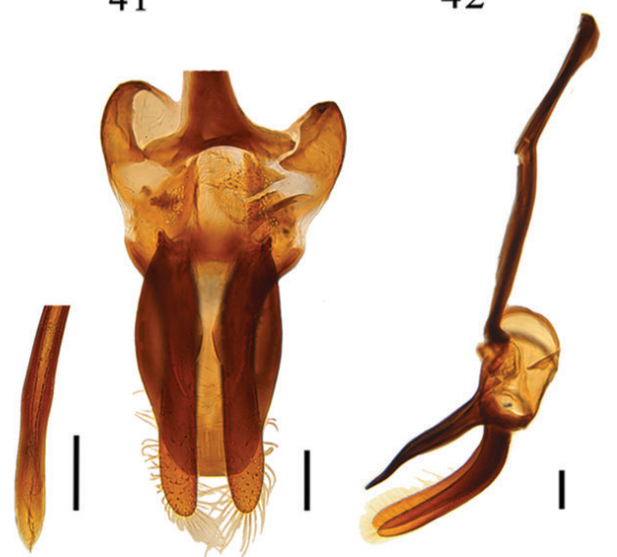

45

46

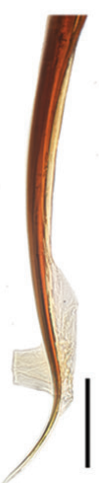

49

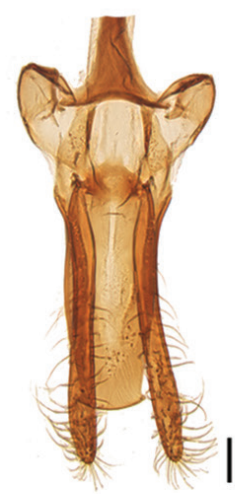

50

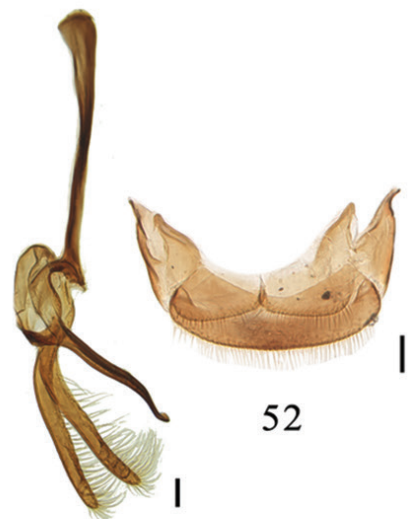

51

Figures 39-52. 39-42 A. nigritus (Pang \& Mao), male genitalia: 39 penis 40 apex of penis 41 tegmen, ventral view 42 tegmen, lateral view 43-47 A. esakii Sasaji, male genitalia: $\mathbf{4 3}$ penis 44 apex of penis 45 apex of penis, ventral view $\mathbf{4 6}$ tegmen, ventral view $\mathbf{4 7}$ tegmen, lateral view 48-52 A. menglensis Huo \& Ren, sp. n. $\mathbf{4 8 - 5}$ I male genitalia: $\mathbf{4 8}$ penis $\mathbf{4 9}$ apex of penis $\mathbf{5 0}$ tegmen, ventral view $\mathbf{5}$ I tegmen, lateral view 52 female genitalia: ovipositor. Scale bars: $0.1 \mathrm{~mm}$. 


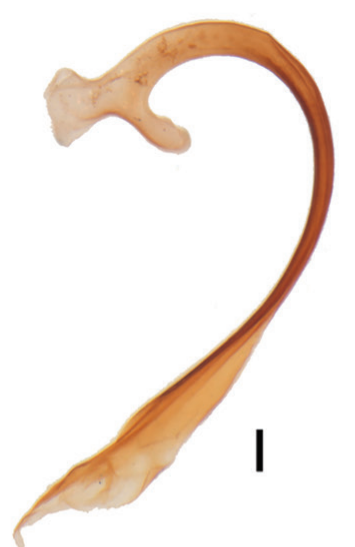

53

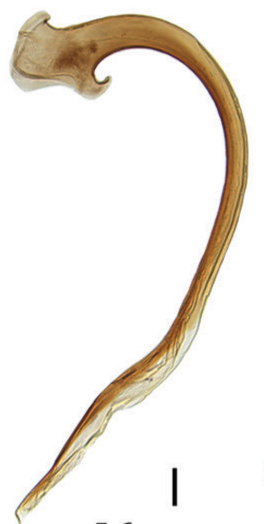

56

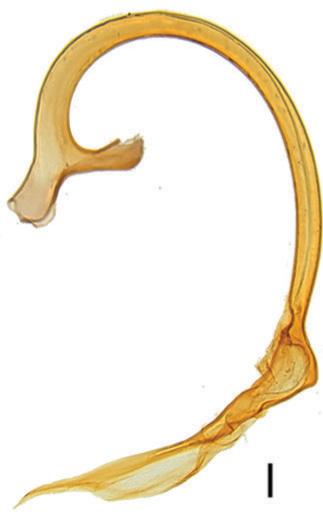

61

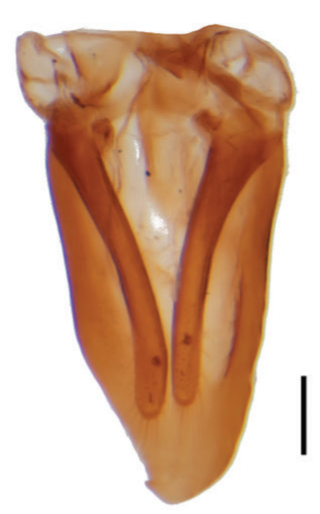

54

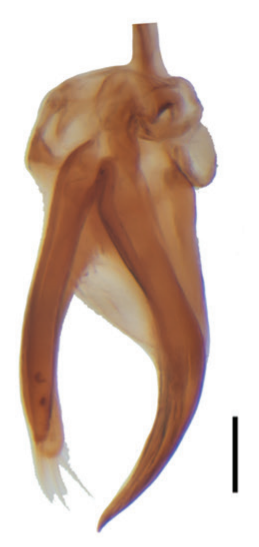

55

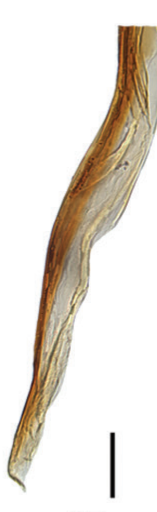

57

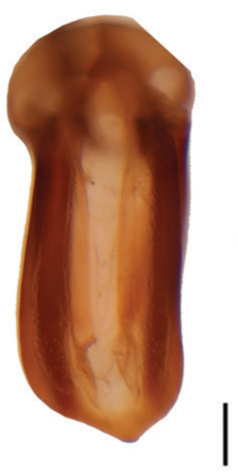

58

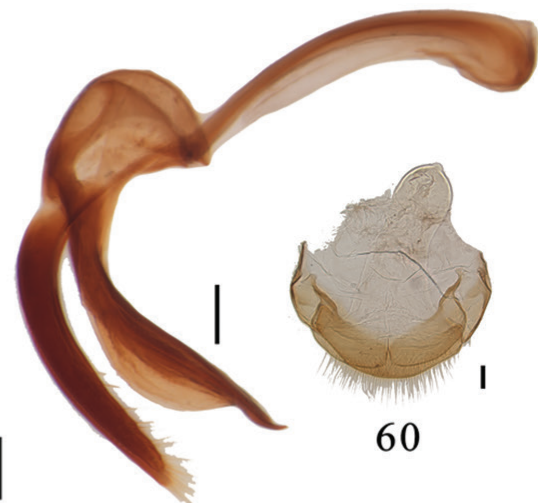

59

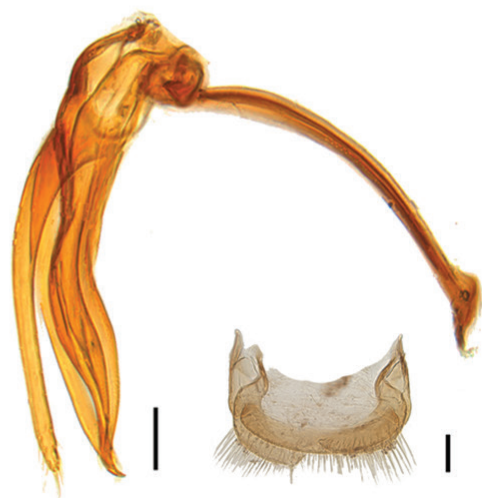

63

Figures 53-64. 53-55 A. guangxiensis Yu, male genitalia: 53 penis 54 tegmen, ventral view 55 tegmen, lateral view 56-60 A. matsumurai Sasaji 56-59 male genitalia: 56 penis $\mathbf{5 7}$ apex of penis $\mathbf{5 8}$ tegmen, ventral view 59 tegmen, lateral view 60 female genitalia: ovipositor 6 I-64 A. kabakovi Hoàng 6 I-63 male genitalia 6 I penis 62 tegmen, ventral view 63 tegmen, lateral view 64 female genitalia: ovipositor. Scale bars: $0.1 \mathrm{~mm}$. 
elytron with 4 black spots besides a black sutural stripe which expanded at near basal and apical part. Elytral spots arranged as follows: spot 1 triangle, situated on humeral callus, spot 2 subrounded, posterior to the transverse middle line, nearer the suture, spot 3 small, oblong, and confluent with the border, spot 4 small, prior apex, confluent with the border (Fig. 30). Underside black, except legs and abdomen reddish brown.

Head small, 0.38 times elytral width $(\mathrm{HW} / \mathrm{EW}=1: 2.64)$. Punctures on frons fine, separated by $0.5-1.0$ times their diameter, with thin, yellow white pubescence. Eyes large and almost oval, finely faceted, the widest interocular distance 0.56 times head width. Pronotum 0.60 times elytral width $(\mathrm{PW} / \mathrm{EW}=1$ : 1.67). Punctures on pronotum and elytra close, separated by $0.5-1.0$ times their diameter, with thick, yellowish pubescence. Underside coarsely punctate, with sparse yellowish pubescence.

Male genitalia: Penis short, penis capsule with an extremely expanded outer process and a short inner process (Fig. 65). Apex of penis with membranous appendage (Fig. 66). In ventral view, penis guide subtriangular, widest at base with a rounded apex (Fig. 67). Penis guide slender and waved, gradually tapering to apex in lateral view, parameres slender, sparsely setose at apex, slightly shorter than penis guide (Fig. 68).

Female genitalia: Unknown.

Specimens examined. Holotype: $1 \delta^{\Uparrow}$, China, Yunnan: Mengzhe, Xishuangbanna, [22 $\left.01.42 ' \mathrm{~N}, 100^{\circ} 17.41^{\prime} \mathrm{E}\right]$, ca $1350 \mathrm{~m}, 26 . v i .1958$, Wang SY leg. (IOZ).

Distribution. China (Yunnan).

\section{Aspidimerus mouhoti Crotch, 1874}

http://species-id.net/wiki/Aspidimerus_mouhoti

Figs 31-32, 69-72, 86

Aspidimerus mouhoti Crotch, 1874: 202; Korschefsky 1931: 172.

Aspidimerus sexmaculatus Pang \& Mao, 1979: 55; Cao and Xiao 1984: 98; Cao et al. 1992: 133; Pang 1998: 186; Kovár 2007: 73, 575; Ren et al. 2009: 110. Synonymized by Kovár 2007: 73.

Diagnosis. This species is similar to A. ruficrus in general appearance, but can be distinguished by the stout, strongly curved penis guide in lateral view and symmetrical with obtuse apex in ventral view (Figs 71-72). In A. ruficrus, penis guide slender, slightly straight in lateral view and vase-shaped with truncate apex in ventral view (Figs 81-82). The shape of penis is also diagnostic (Fig. 69).

Description. TL: $4.80 \mathrm{~mm}$, TW: $3.60 \mathrm{~mm}$, TH: $1.58 \mathrm{~mm}$, TL/TW: 1.33 ; PL/PW: 0.33; EL/EW: 1.14 .

Body relatively large, oval, dorsum convex and pubescent (Fig. 32). Head yellowish brown in male and reddish brown in female. Eyes black. Clypeus, mouthparts and antennae reddish brown. Pronotum black with anterior corner yellowish brown (Fig. 31). Scutellum black. Elytra yellowish brown with 3 black spots on each elytron, spot 1 subrounded, situated on humeral callus, spot 2 long oval, largest, situated on middle 


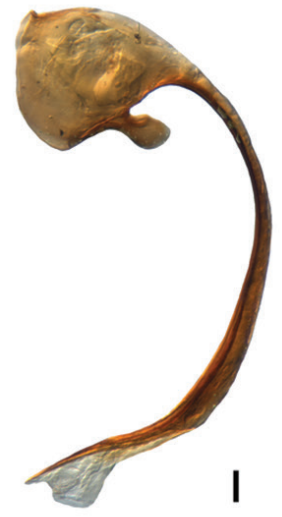

65

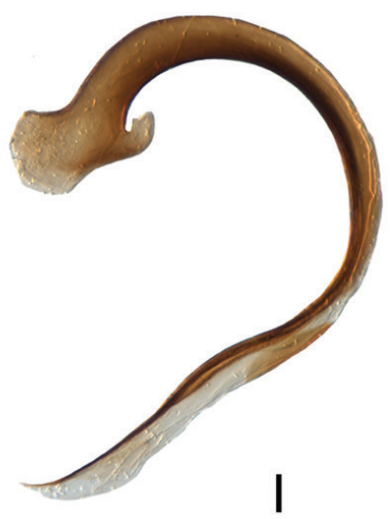

69

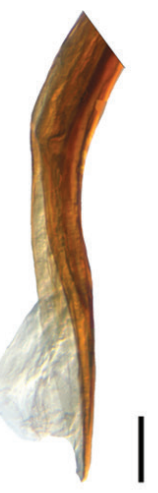

66

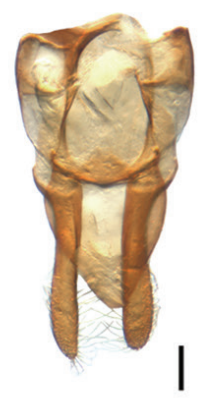

67

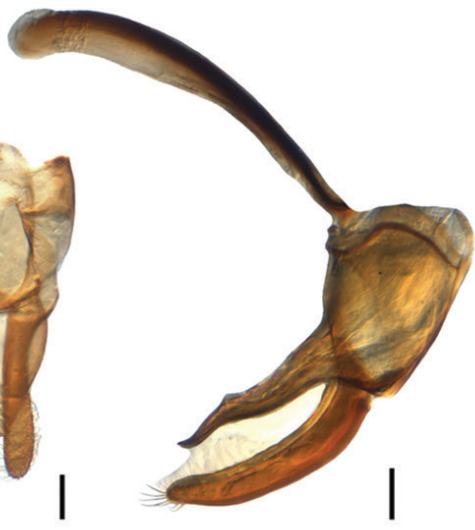

68

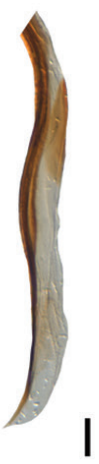

70

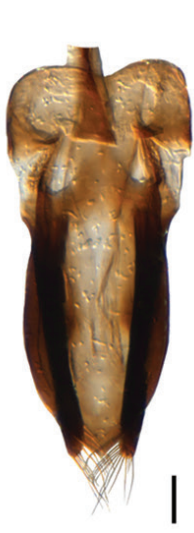

71

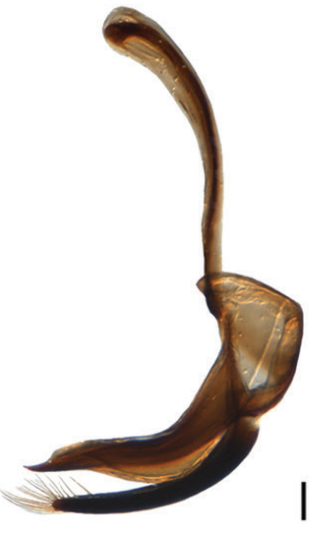

72

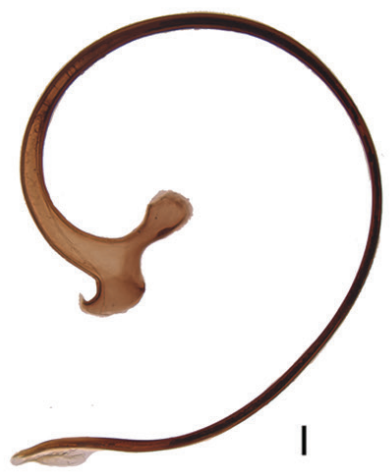

73

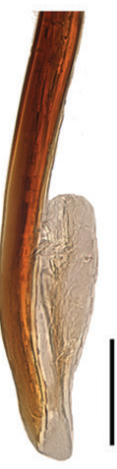

74

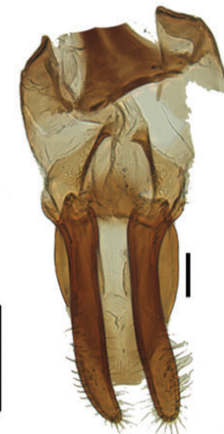

75
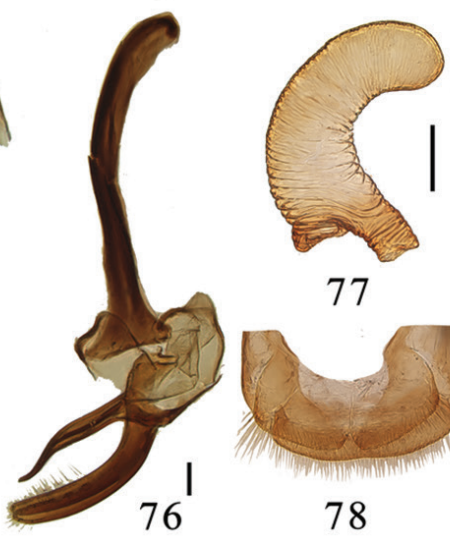

77

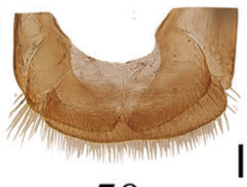

78

Figures 65-78. 65-68 A. decemmaculatus Pang \& Mao, male genitalia: 65 penis 66 apex of penis 67 tegmen, ventral view 68 tegmen, lateral view 69-72 A. mouhoti Crotch, male genitalia: 69 penis $\mathbf{7 0}$ apex of penis $\mathbf{7 I}$ tegmen, ventral view $\mathbf{7 2}$ tegmen, lateral view 73-78 A. zhenkangicus Huo \& Ren, sp. n. 73-76 male genitalia: $\mathbf{7 3}$ penis $\mathbf{7 4}$ apex of penis $\mathbf{7 5}$ tegmen, ventral view $\mathbf{7 6}$ tegmen, lateral view 77-78 female genitalia: $\mathbf{7 7}$ spermatheca $\mathbf{7 8}$ ovipositor. Scale bars: $0.1 \mathrm{~mm}$. 
of elytra, spot 3 smaller, oblong, and extending to the apex confluent with the border (Figs 31-32). Lateral margins black. Underside reddish brown except prosternum, mesoventrite and metaventrite black.

Head transverse and ventrally flattened, 0.36 times elytral width (HW/EW=1: 2.77). Punctures on frons moderately large, separated by $0.5-1.0$ times their diameter, with short sparsely distributed setae. Eyes moderately large and finely faceted, widest interocular distance 0.62 times head width. Pronotum 0.70 times elytral width (PW/EW=1: 1.43 ), closely covered with fine punctures associated with long dense pubescence, punctures smaller than those on head, separated by $0.5-1.5$ times their diameter. Punctures on elytra very fine and close, similar to those on pronotum, with dense silver white pubescence. Prosternum coarse, with sparse long yellowish pubescence. Punctures on metaventrite moderately large, separated by $0.5-1.0$ times their diameter, with dense yellowish pubescence.

Male genitalia: Penis short and stout, strongly curved at basal half, apical half with membranous appendage (Figs 69-70). Penis capsule with a large outer process and a small, unciform inner process (Fig. 69). Penis guide stout and strongly curved in lateral view (Fig. 72). In ventral view, penis guide symmetrical, widest at middle and converging gradually to a blunted tip (Fig. 71). Parameres slender, equal in length to penis guide, sparsely setose at apex (Fig. 72)

Female genitalia: Unknown.

Specimens examined. $1 \widehat{O}^{\lambda}$, China, Yunnan: Menghun, Xishuangbanna, [2150.56'N, $\left.100^{\circ} 23.02^{\prime} \mathrm{E}\right]$, ca 1200m, 15.vi.1958, Pu FJ leg. (Holotype of Aspidimerus sexmaculatus Pang \& Mao, IOZ).

Distribution. China (Yunnan); Laos (Mouhot).

\section{Aspidimerus zhenkangicus Huo \& Ren, sp. n.} http://zoobank.org/F3B523AB-4599-4496-BD86-D437E3C60D1E http://species-id.net/wiki/Aspidimerus_zhenkangicus

Figs 33-35, 73-78, 86

Diagnosis. This species closely resembles A. ruficrus in elytral color pattern (Figs 33, 36), but male genitalia are quite different (Figs 73-76;79-82). It is also similar to A. esakii in male genitalia, but can be distinguished from the latter by the elytra yellow with 7 black spots (Fig. 33), apex of penis with relatively small membranous appendage (Fig. 73), different shape of penis capsule (Figs 43, 73) and more narrowly truncate apex of penis guide in ventral view (Figs 46,75). The spermatheca (Fig. 77) is also different from that of $A$. esakii given by Sasaji (1968).

Description. TL: $4.50-4.75 \mathrm{~mm}$, TW: $3.40-3.60 \mathrm{~mm}$, TH: $2.00-2.25 \mathrm{~mm}$, TL/ TW: 1.32; PL/PW: 0.54-0.56; EL/EW: 1.04-1.06.

Body medium size and oval, dorsum moderately convex and pubescent (Fig. 33-35). Head dark yellow with basal margin and clypeus reddish brown, eyes black. Pronotum black, except anterior corners dark yellow (Fig. 35). Scutellum black. Elytra yellowish brown with black sutural stripe distinctly expanded near basal half (Fig. 33). 
Elytral margins black. Each elytron with 3 black spots arranged as Fig. 34. Underside reddish brown, except legs dark yellow.

Head small, 0.44 times elytral width $(\mathrm{HW} / \mathrm{EW}=1: 2.27)$. Surface of head with fine punctures, separated by $0.3-1.0$ times their diameter, with thick, yellowish pubescence. Eyes large and almost oval, rather finely faceted, the widest interocular distance 0.50 times head width. Pronotum 0.71 times elytral width (PW/EW=1: 1.42). Punctation on pronotum sparser than on head, separated by 1.0-1.5 times their diameter, with thick, yellowish pubescence. Surface of elytra densely pubescent and sparsely punctate, punctures separated by $0.5-2.0$ times their diameter. Underside finely punctate, with pubescence dense, moderately long and yellowish.

Male genitalia: Penis relatively long, slender, curved almost in a circle. Penis capsule with a short outer process and a long inner one, apex of penis with relatively small membranous appendage (Figs 73-74). Penis guide slender, gradually tapering to apex in lateral view (Fig. 76). In ventral view, penis guide short oval, widest at base with truncate apex (Fig. 75). Parameres slender, densely setose along almost half of their length, longer than penis guide (Fig. 76).

Female genitalia: Tenth tergite broad with terminal setae. Coxites subtriangular with moderately long terminal setae (Fig. 78). Spermatheca vermiform with wide nodulus and long ramus (Fig. 77).

Types. Holotype: $10^{\lambda}$, China, Yunnan: Mengdui, Zhenkang, $\left[23^{\circ} 53.47^{\prime} \mathrm{N}\right.$, 98 $53.33^{\prime} \mathrm{E}$ ], ca 1400m, 18.vi.2008, Wang XM leg. (SCAU). Paratypes (5): Yunnan: $10^{\top}$, Longmen, Mengla, [21 $\left.{ }^{\circ} 15.12^{\prime} \mathrm{N}, 101^{\circ} 38.52^{\prime} \mathrm{E}\right]$, ca $1030 \mathrm{~m}, 9 . \mathrm{v} .2009$, Ren SX leg.

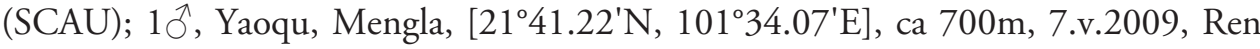

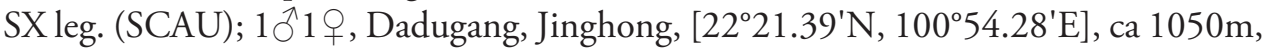
5.v.2009, Wang XM leg. (SCAU); 1 엉, Xiaomengyang, Xishuangbanna, $\left[22^{\circ} 04.50^{\prime} \mathrm{N}\right.$, $\left.100^{\circ} 54.18^{\prime} \mathrm{E}\right]$, ca $790 \mathrm{~m}, 27 . i v .2008$, Wang XM leg. (SCAU).

Distribution. China (Yunnan).

Etymology. The specific epithet refers to the location of the holotype, Zhenkang, Yunnan.

\section{Aspidimerus ruficrus Gorham, 1895}

http://species-id.net/wiki/Aspidimerus_ruficrus

Figs 36-38, 79-84, 86

Aspidimerus ruficrus Gorham, 1895: 690; Korschefsky 1931: 173; Kapur 1948: 83;

Pang and Mao 1979: 55; Cao and Xiao 1984: 98; Cao et al. 1992: 134; Pang

1998: 186; Kováŕ 2007: 575; Ren et al. 2009: 108; Poorani 2002: 343.

Cryptogonus blandus Mader, 1954: 130; Liu 1963: 84. syn. n.

Aspidimerus blandus (Mader, 1954): Kovár 2007: 73. Combined by Kovář 2007: 73.

Diagnosis. This species is similar to $A$. mouhoti in general appearance, but can be distinguished by the penis guide slender and slightly straight in lateral view and vase- 


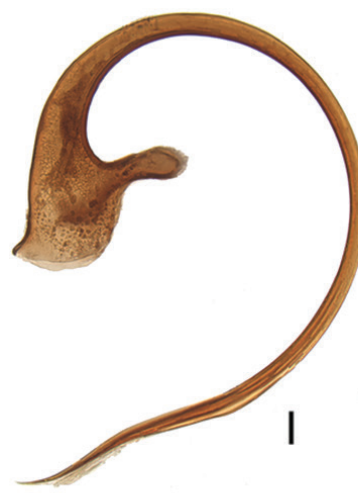

79

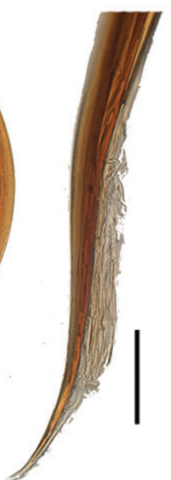

80

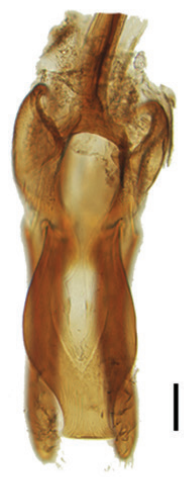

81

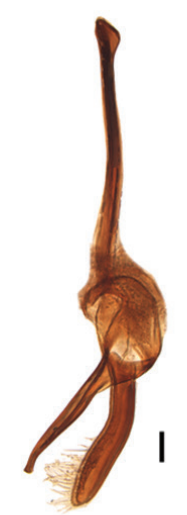

82

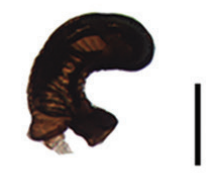

83

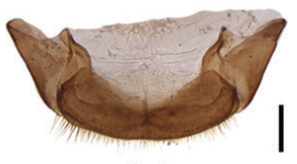

84

Figures 79-84. A. ruficrus Gorham, 79-82 male genitalia: $\mathbf{7 9}$ penis $\mathbf{8 0}$ apex of penis $\mathbf{8} \mathbf{I}$ tegmen, ventral view $\mathbf{8 2}$ tegmen, lateral view $\mathbf{8 3 - 8 4}$ female genitalia: $\mathbf{8 3}$ spermatheca $\mathbf{8 4}$ ovipositor. Scale bars: $0.1 \mathrm{~mm}$.

shaped with truncate apex in ventral view (Figs 81-82). The shape of penis is also diagnostic (Fig. 79).

Description. TL: $3.75-4.00 \mathrm{~mm}$, TW: $3.00-3.25 \mathrm{~mm}$, TH: $1.55-1.65 \mathrm{~mm}$, TL/ TW: 1.23-1.25; PL/PW: 0.54-0.56; EL/EW: 0.98-1.00.

Body oblong oval, dorsum moderately convex and pubescent (Figs 36-38). Head deep yellow in male and black in female. Eyes black or silver. Pronotum black with anterior corners deep yellow (Fig. 38). Scutellum black. Elytra deep yellow with a black border along all the margins and three black spots (Figs 36-37). Spot 1 rounded, situated on humeral callus. Spot 2 subrounded, largest, posterior to the transverse middle line, nearer the suture. Spot 3 small, oblong, and confluent with the lateral margin. Underside black, except legs and abdomen reddish brown.

Head small and transverse, 0.43 times elytral width $(\mathrm{HW} / \mathrm{EW}=1: 2.31)$. Punctures on frons finer, separated by $0.5-1.0$ times their diameter, with thin, yellow white pubescence. Eyes moderately large and rather finely faceted, the widest interocular distance 0.31 times head width. Pronotum convex and transverse, 0.68 times elytral width $(\mathrm{PW} / \mathrm{EW}=1: 1.46)$, covered with finely close punctures associated with dense yellowish pubescence. Punctures on elytra fine and close, smaller than those on pronotum, separated by 1.0-2.0 times their diameter, with dense silver white pubescence. Scutellum subtriangular. Punctures on prosternum coarse, with sparse long pubescence. Mesoventrite with yellow white pubescence. Metaventrite coarsely punctate, separated by $0.3-0.5$ times their diameter, with pubescence sparse, moderately long and yellowish.

Male genitalia: Penis long, curved almost in a circle. Penis capsule with an expanded outer process and a small inner one (Fig. 79). Apex of penis with membranous appendage (Fig. 80). Penis guide slender and nearly straight in lateral view (Fig. 82). In ventral view, penis guide vase-shaped, widest at middle, with truncate apex (Fig. 81). Parameres slender, equal in length to penis guide, sparsely setose at apex (Fig. 82). 


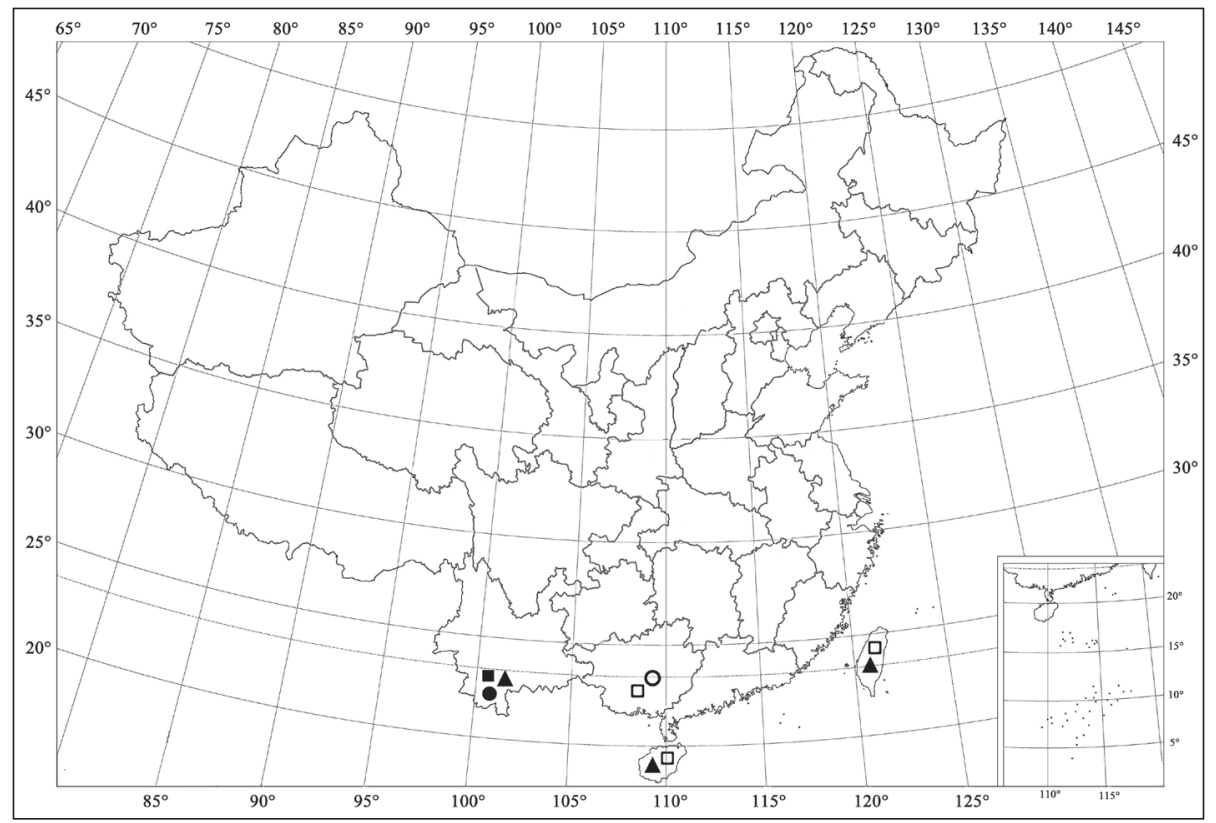

Figures 85. Distribution map. Aspidimerus nigritus (Pang \& Mao) (ロ); Aspidimerus esakii Sasaji ( $\square$ ); Aspidimerus menglensis Huo \& Ren, sp. n. (•); Aspidimerus guangxiensis Yu (०); Aspidimerus matsumurai Sasaji $(\mathbf{\Lambda})$.

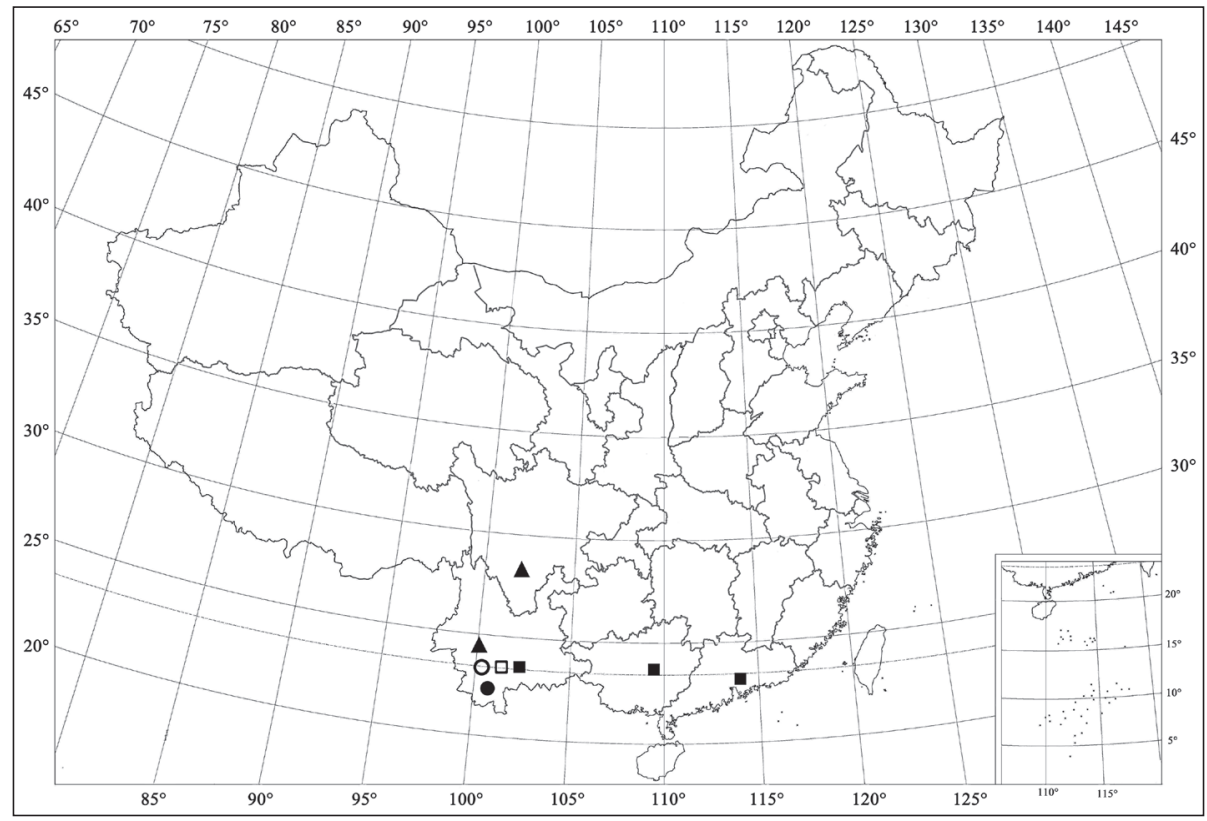

Figures 86. Distribution map. Aspidimerus kabakovi Hoàng (घ); Aspidimerus decemmaculatus Pang \& Mao ( $\square)$; Aspidimerus mouhoti Crotch (•); Aspidimerus zhenkangicus Huo \& Ren, sp. n. (०); Aspidimerus ruficrus Gorham ( $\mathbf{\Delta})$. 
Female genitalia: Tenth tergite moderately broad and coxites subtriangular, each with a few long terminal setae (Fig. 84). Spermatheca with a wide nodulus, a stout cornu and a short ramus (Fig. 83).

Specimens examined. China, Yunnan: $2{ }^{\lambda} 1$ 우, Longmen, Mengla, [ $\left[21^{\circ} 15.12^{\prime} \mathrm{N}\right.$, $\left.101^{\circ} 38.52^{\prime} \mathrm{E}\right]$, ca $1030 \mathrm{~m}$, 9.v.2009, Ren SX leg (SCAU); 19, Longmen, Mengla, [21 $\left.30.17^{\prime} \mathrm{N}, 101^{\circ} 31.44^{\prime} \mathrm{E}\right]$, ca $760 \mathrm{~m}, 1 . v .2008$, Wang XM leg (SCAU); 1 , , Mengdui, Zhenkang, [235 $53.47^{\prime} \mathrm{N}, 98^{\circ} 53.33^{\prime} \mathrm{E}$ ], 1400m, 18.v.2008, Wang XM leg (SCAU).

Distribution. China (Sichuan, Yunnan); Vietnam; Burma.

Remarks. Mader (1954) described the species Cryptogonus blandus based on 1 male and 3 female specimens which were collected from Yunnan, China. Liu (1963) recorded C. blandus Mader in his monography and mentioned that this species belongs to the genus Aspidimerus according to the character of its prosternal lines. Kovár (2007) transferred C. blandus to the genus Aspidimerus without further explanation. An examination of the specimens of $A$. blandus (Mader) collected from type locality show that the characters of the adult, including the male genitalia, were in perfect agreement with the descriptions and illustrations of A. ruficrus given by Kapur (1948). Therefore, we considered $A$. blandus (Mader, 1954) as a junior synonym of $A$. ruficrus Gorham, 1895.

\section{Catalogue of Aspidimerus Mulsant, 1850}

Aspidimerus Mulsant, 1850: 944. Type species: Aspidimerus spencii Mulsant, 1850. Aspidimerus Mulsant: Gorham 1895: 690. Crotch 1874: 202; Weise 1885: 232; 1900: 426; Mader 1926: 16; Korschefsky 1931: 172; Kapur 1948: 81; Sasaji 1968: 15; Pang and Mao 1979: 53; Hoàng 1982: 161; Pang 1998: 185; Poorani 2002: 343; Yu and Li 2004: 329; Ren et al. 2009: 106.

Aspidimerus birmanicus (Gorham, 1895)

Cryptogonus birmanicus Gorham, 1895: 691.

Aspidimerus birmanicus (Gorham): Kapur 1948: 84; Poorani 2002: 343. Combined by Kapur 1948: 84 .

Distribution. Burma; Thailand.

Aspidimerus chapaensis Hoàng, 1982

Aspidimerus chapaensis Hoàng, 1982: 166.

Distribution. Vietnam.

Aspidimerus decemmaculatus Pang \& Mao, 1979

Aspidimerus decemmaculatus Pang \& Mao, 1979: 56; Cao and Xiao 1984: 98; Cao et al. 1992: 134; Pang 1998: 186; Kováŕ 2007: 575; Ren et al. 2009: 106.

Distribution. China (Yunnan). 
Aspidimerus esakii Sasaji, 1968

Aspidimerus esakii Sasaji, 1968: 16; Pang and Mao 1979: 54; Pang 1998: 185; Yu 1995: 139; 2011: 166; Kováŕ 2007: 575; Ren et al. 2009: 106.

Distribution. China (Hainan, Guangxi, Taiwan).

Aspidimerus guangxiensis $\mathrm{Yu}, 2004$

Aspidimerus guangxiensis Yu, 2004: 329; Ren et al. 2009: 106.

Distribution. China (Guangxi).

Aspidimerus kabakovi Hoàng, 1982

Aspidimerus kabakovi Hoàng, 1982: 167.

Distribution. China (Guangdong, Guangxi, Yunnan); Vietnam.

Aspidimerus laokayensis Hoàng, 1982

Aspidimerus laokayensis Hoàng, 1982: 164.

Distribution. Vietnam.

Aspidimerus matsumurai Sasaji, 1968

Aspidimerus matsumurai Sasaji, 1968: 17; Pang and Mao 1979: 53; Hoàng 1982: 162;

Cao and Xiao 1984: 98; Cao et al. 1992: 131; Pang 1998: 185; Kovár 2007: 575;

Ren et al. 2009: 108; Yu 2011: 167.

Distribution. China (Yunnan, Hainan, Taiwan); Vietnam.

Aspidimerus menglensis Huo \& Ren, sp. n.

Aspidimerus menglensis Huo \& Ren, sp. n.

Distribution. China (Yunnan).

Aspidimerus mouboti Crotch, 1874

Aspidimerus mouhoti Crotch, 1874: 202. Korschefsky 1931: 172.

Aspidimerus sexmaculatus Pang \& Mao, 1979: 55; Cao and Xiao 1984: 98; Cao et al. 1992: 133; Pang 1998: 186; Kovár 2007: 73, 575; Ren et al. 2009: 110. Synonymized by Kovár 2007: 73.

Distribution. China (Yunnan); Laos (Mouhot).

Aspidimerus nigritus (Pang \& Mao, 1979)

Cryptogonus nigritus Pang \& Mao, 1979: 61; Cao et al. 1992: 138.

Aspidimerus dongpaoensis Hoàng, 1982: 165. Synonymized by Kováŕ 2007: 73.

Aspidimerus nigritus (Pang \& Mao): Kovár 2007: 71, 73, 575; Ren et al. 2009: 108.

Combined by Kovář 2007: 71.

Distribution. China (Yunnan); Vietnam. 
Aspidimerus nigrovittatus Motschulsky, 1866

Aspidimerus nigrovittatus Motschulsky, 1866: 424; Crotch 1874: 202; Weise 1900: 428; Korschefsky 1931: 172; Poorani 2002: 343.

Distribution. Sri Lanka.

Aspidimerus ruficrus Gorham, 1895

Aspidimerus ruficrus Gorham, 1895: 690; Korschefsky 1931: 173; Kapur 1948: 83;

Pang and Mao 1979: 55; Cao and Xiao 1984: 98; Cao et al. 1992: 134; Pang

1998: 186; Kovár 2007: 575; Ren et al. 2009: 108; Poorani 2002: 343.

Cryptogonus blandus Mader, 1954: 130; Liu 1963: 84.

Aspidimerus blandus (Mader, 1954): Kovár 2007: 73. Combined by Kovár 2007: 73. syn. n.

Distribution. China (Sichuan, Yunnan); Vietnam; Burma.

Aspidimerus spencii Mulsant, 1850

Aspidimerus spencii Mulsant, 1850: 944; Crotch 1874: 202; Weise 1885: 232; Korschefsky 1931: 173; Kapur 1948: 83; Poorani 2002: 343.

Distribution. India; Burma.

Aspidimerus zhenkangicus Huo \& Ren, sp. n. Aspidimerus zhenkangicus Huo \& Ren, sp. n.

Distribution. China (Yunnan).

\section{Acknowledgements}

The authors sincerely thank Kong DL and Li WJ (College of Natural Resources and Environment, South China Agricultural University, China) for their help during this research work. The research was supported by the National Natural Science Foundation of China (2006FY120100, 2008FY210500).

\section{References}

Cao CY, Pan Y, Wang H (1992) Coccinellidae of Yunnan. Yunnan Science \& Technology Publishing House, Kunming, 242 pp. [In Chinese]

Cao CY, Xiao NN (1984) A check list of ladybeetles from Yunnan Province. Journal of Southweatern Forestry College 1: 92-105. [In Chinese]

Chapuis F (1876) In: Lacordaire T, Chapuis F (Eds) Histoire Naturelle des Insectes, Genera des Coléoptères, Vol. 12. Roret, Paris.

Crotch GR (1874) A Revision of the Coleopterous Family Coccinellidae. E. W. Janson, London, 311 pp. doi: 10.5962/bhl.title. 8975 
Gorham HS (1895) On the Coccinellidae collected by Mr. L. Fea in Burma. Annali del Museo Civicodi Storia Naturale, Genova, (2)34: 683-695.

Hoàng DN (1982) Coccinellidae of Vietnam Part I. Nha xuat ban khoa hoc va ky thuat, Hanoi,

211 pp. [In Vietnamese with English summary]

Kovár I (2007) Coccinellidae. In: Löbl I, Smetana A (Ed) Catalogue of Palaearctic Coleoptera, Volume 4. Apollo Books, Stenstrup, 71-73, 568-631.

Kapur AP (1948) A revision of the tribe Aspidimerini Weise (Coleoptera, Coccinellidae).

Transactions of the Royal Entomological Society of London 99: 77-128. doi: 10.1111/ j.1365-2311.1948.tb01233.x

Korschefsky R (1931) Coleopterorum Catalogus. Pars 118. Coccinellidae I. Berlin, 224pp.

Kuznetsov V, Pang H (1991) Description of Four New Aspidimerini (Coleoptera, Coccinellidae) from Vietnam. Elytra, Tokyo, 19(2): 185-190.

Liu CL (1963) Economic Insects of China, Fasc. 5, Coleoptera: Coccinellidae. Science Press, Beijing, 1963, 101 pp. [In Chinese]

Mader L (1954) Weiteres über Coccinelliden aus der Sammlung des Naturhistorischen Museums in Wien. Koleopterologische Rundschau 32 (1951-1954): 123-131.

Motschulsky V (1866) Essai d'un Catalogue des Insectes de I'ile de Ceylan. Supplément. Bulletin de la Société impériale des naturalistes de Moscou 39(1): 393-446.

Mulsant E (1850) Species des Coléoptères trimères sécuripalpes. Annales des Sciences Physiques et Naturelles, d'Agriculture et d'Industrie, Lyon (2) 2: 1-1104.

Pang H (1998) The new record and new species of Aspidimerinae (Coleoptera: Coccinellidae) from China. Entomotaxonomia 20(3): 185-193.

Pang H, Ren SX, Zeng T, Pang XF (2004) Biodiversity and their utilization of Coccinellidae in China. Science and Technology Press of Guangdong, Guangzhou, 168 pp.

Pang XF, Mao JL (1979) Economic Entomology of China 14: Coleoptera Coccinellidae II. Science Press, Beijing, 170 pp.

Poorani J (2002) An annotated checklist of the Coccinellidae (Coleoptera) (excluding Epilachninae) of the Indian subregion. Oriental Insects 36: 307-383. doi: 10.1080/00305316.2002.10417335

Ren SX, Wang XM, Pang H, Peng ZQ, Zeng T (2009) Colored pictorial handbook of ladybird beetles in China. Science Press, Beijing, 336 pp.

Sasaji H (1968) A revision of the Formosan Coccinellidae (II): Tribe Stethorini, Aspidimerini and Chilocorini (Coleoptera). Etizenia, Fukui (32): 1-24.

Ślipiński A (2007) Australian ladybird beetles (Coleoptera: Coccinellidae) their biology and classification. ABRS, Canberra, 286 pp.

Ślipiński A, Tomaszewska W (2010) Coccinellidae Latreille, 1802. In: Leschen RAB, Beutel RG, Lawrence JF (Eds) Handbook of Zoology, 2, Coleoptera. Walter de Gruyter GmbH \& Co KG, Berlin, New York, 454-472.

Yu GY (1995) The Coccinellidae (Excluding Epilachinae) collected by J. Klapperich in 1977 on Taiwan. Spixiana 18(2): 123-144.

Yu GY (2011) The Coccinellidae of Taiwan. Chemical Industry Press, Beijing, 198 pp.

Yu GY, Li HX (2004) Coleoptera-Coccinellidae. In: Yang X (Ed) Insects from Mt. Shiwandashan Area of Guangxi. China Forestry Publishing House, Beijing, 326-338. 
Weise J (1885) Beschreibung einiger Coccinelliden. Stettiner Entomologische Zeitung 46: 227-242.

Weise J (1900) Coccinelliden aus Ceylon gesammelt von Dr. Horn. Deutsche Entomologische Zeitschrift 44: 417-448. 